\title{
1 Study of the planetary boundary layer by microwave 2 radiometer, elastic lidar and Doppler lidar estimations in 3 Southern Iberian Peninsula
}

4 Gregori de Arruda Moreira' ${ }^{1,2,3}$, Juan Luis Guerrero-Rascado, ${ }^{1,2}$, Juan Antonio Bravo5 Aranda ${ }^{1,2,6}$, José Antonio Benavent-Oltra ${ }^{1,2}$, Pablo Ortiz-Amezcua ${ }^{1,2}$, Roberto Róman ${ }^{1,2,4}$, 6 Andrés Esteban Bedoya-Velásquez ${ }^{1,2,5}$ Eduardo Landulfo ${ }^{3}$, Lucas Alados-Arboledas ${ }^{1,2}$

$7 \quad{ }^{1}$ Andalusian Institute for Earth System Research (IISTA-CEAMA), Granada, Spain

$8 \quad{ }^{2}$ Dpt. Applied Physics, University of Granada, Granada, Spain

$9 \quad{ }^{3}$ Institute of Research and Nuclear Energy (IPEN), São Paulo, Brazil

$10 \quad{ }^{4}$ Atmospheric Optics Group (GOA), University of Valladolid, Valladolid, Spain

11 5 Sciences Faculty, Department of Physics, Universidad Nacional de Colombia, Medellín, Colombia.

12 ' ${ }^{6}$ Insitute Pierre Simon Laplace, France

Correspondence to: Gregori de Arruda Moreira (gregori.moreira@usp.br)

https://doi.org/10.1016/i.atmosres.2018.06.007

\section{Abstract}

The Planetary Boundary Layer $(P B L)$ is a relevant part of the atmosphere with a variable extension that clearly plays an important role in fields like air quality or weather forecasting. Passive and active remote sensing systems have been widely applied to analyze $P B L$ characteristics. The combination of different remote sensing techniques allows obtaining a complete picture on the PBL dynamic. In this study, we analyze the $P B L$ using microwave radiometer, elastic lidar and Doppler lidar data. We use co-located data simultaneously gathered in the framework of SLOPE-I (Sierra Nevada Lidar aerOsol Profiling Experiment) campaign at Granada (Spain) during a 90- day period in summer 2016. Firstly, the PBL height (PBLH) obtained from microwave radiometer data is validated against $P B L H$ provided by analyzing co-located radiosondes, showing a good agreement. In a second stage, active remote sensing systems are used for deriving the $P B L H$. Thus, an extended Kalman filter method is applied to data obtained by the elastic lidar while the vertical wind speed variance method is applied to the Doppler lidar. $P B L H^{\prime} S$ derived by these approaches are compared to $P B L H$ retrieved by the microwave radiometer. The results show a good agreement among these retrievals based on active remote sensing in most of the cases, although some discrepancies appear in instances of intense $P B L$ changes (either growth and/or decrease).

\section{Introduction}

The Planetary Boundary Layer $(P B L)$ is defined as the "part of the troposphere that is directly influenced by the presence of the Earth's surface, and responds to surface forcings with a time scale of about an hour or less" (Stull, 1988). This layer has high variability, being characterized by a daily cycle and presence of turbulent processes. In an ideal situation, some instants after the sunrise the ground surface temperature begins to increase, due to positive net radiative flux. Then, the air masses situated close to the ground get warmer and a convective process starts due to the buoyancy of these air masses that transport heat to the upper atmospheric layers. According to Stull et al., 1988 this process originates an unstable layer 
denominated Convective Boundary Layer $(C B L)$ or Mixing Layer $(M L)$. Close to sunset, the reduction of incidence of solar radiation causes gradual suppression of the convective processes, resulting in a weak and sporadic turbulence. Then, the $C B L$ becomes two different layers: an stably stratified shallow boundary layer called Stable Boundary Layer $(S B L)$, and the Residual Layer $(R L)$, which still remains with the features from previous day's $C B L$ and above the $S B L$. This cyclical process will start again with the next sunrise.

The $P B L$ Height $(P B L H)$ is an important parameter for a wide set of studies, which include pollutant dispersion, weather forecasting, meteorological modeling and air quality (Li et al., 2017). Although the $P B L H$ cannot be measured directly, some atmospheric variables (e.g., potential temperature $(\theta)$, vertical wind speed $(w)$, relative humidity $(R H)$ and aerosol distribution) have characteristic profiles due to turbulent vertical processes that enable its detection (Stull, 1988). In addition, surface variables also can be used as proxy for $P B L H$ detection, e.g. sensible heat flux (Haeffelin, et al., 2012). The use of radiosounding is by practical and historical issues the most widespread method in $P B L H$ detection along years (Seidel et al., 2010). However, the high variability of $P B L$ during its daily cycle requires systems endowed with high temporal resolution for continuous monitoring, which is not covered when launching radiosondes. In this scenario, remote sensing systems had risen as an important tool in $P B L$ studies, providing detailed and long-term observational PBLH information (e.g. He et al., 2006; Granados-Muñoz et al., 2012; Di Giuseppe et al., 2012; Haman et al., 2012; Pal et al., 2013; Coen et al., 2014; Korhonen et. al, 2014; Pal et al., 2015).

In the last two decades, elastic lidar $(E L)$ systems have been widely applied in $P B L$ studies (Flamant et al., 1997; Menut et al., 1999; Davis et al., 2000; Brooks et al., 2003; Morille et al., 2007; Münkel, et al., 2007; Baars et al., 2008; Pal et al., 2010; De Tomasi et al., 2011; Haeffelin et al., 2012; Wang et al., 2012; Granados-Muñoz et al., 2012; Lange et al., 2014; Fedele et al., 2015; Banks et al., 2016; Bravo-Aranda et al., 2017; Liu et al., 2018, Zhu et al., 2018). The detection of the PBLH using EL (PBLH elastic $\left._{\text {) }}\right)$ is based on the definition provided by Deardorff et al. (1980) for this variable: "the altitude where there are equals areas of clear air below and particulates above", e.g. considering an ideal lidar return the PBLH is at the midpoint where an inflexion occurs and the areas below and above the lidar return curve are equal (Kovalev and Eichinger, 2004). Thus, when $P B L$ is fully developed the height of $C B L\left(P B L H_{\text {elastic }}^{C B L}\right)$ is detected, otherwise the $R L$ Height $\left(P B L H_{\text {elastic }}^{R L}\right.$ ) is observed instead. However, it is not easy to find this midpoint by the use of real $E L$ signals due to either low signal-to-noise ratio or complex vertical distribution of the atmospheric aerosols such as the presence of aerosol multilayers or clouds (Kovalev and Eichinger, 2004). To solve this issue, mathematical methods are applied to the $E L$ signal to reduce ambiguities in analyzed signals. The traditional algorithms applied in $P B L H_{\text {elastic }}$ detection are the Gradient Method (Menut, et al. 1999; Martucci et al., 2007; Baars et al., 2008; Li et al., 2017; Zhu et al., 2018), Variance or Centroid Method (Hooper and Eloranta, 1986; Menut et al., 1999; Martucci et al., 2007), Threshold Method (Melfi et al., 1985; Kovalev and Eichinger, 2004), Fit Method (Eresma et al., 2006; Li et al., 2017) and Wavelet Covariance Transform (Davis et al., 2000; Granados-Muñoz et al., 2012; Lopes et al., 2014). However, these methods can still overestimates $P B L H_{\text {elastic }}$ on the mentioned complex situations. Lange et al. (2014), Bravo-Aranda et al. (2017) and Liu et al. (2018) proposed algorithms to overcome these situations, using a method based on Extended Kalman Filter, information from depolarization lidar channels and combination 
between aerosol color ratio and depolarization ratio, respectively, the drawback however is obvious as not as lidar systems are polarization-sensitive. Another shortcoming of the detection of $S B L$ technique is the high range for full overlap of some systems, which for azimuth pointing systems can be considered altitude dependent, what might prevent a correct detection of the $S B L$ that is typically found at lower heights.

Doppler lidars ( $D L$ ) have been also used for $P B L$ studies (Avolio et al., 2017; Das et al., 2018), mainly in $P B L H$ detection $\left(P B L H_{\text {Doppler }}\right.$ ), so that the most applied algorithms with these systems are based on either $M L$ definition or turbulence threshold. The methods that use $M L$ definition are the same $E L$ methods mentioned above using the backscattered signal (Shukla et al, 2014), however the carrier-to-noise ratio $(C N R)$ profile also can be applied in some algorithms, e.g. variance method (Moreira et. al, 2015). In these cases, similarly to $E L$, when $P B L$ is fully developed the height of $C B L\left(P B L H_{D o p p l e r}^{C B L}\right)$ is detected, otherwise the height RL ( $P B L H_{D o p p l e r}^{R L}$ ) is observed. The main methods based on turbulence threshold are the variance of vertical wind speed $\left(\sigma_{w}^{2}\right)$ (Barlow et al., 2011; Schwenn et al., 2014), low-level jets detection (Moreira et al., 2015), turbulent energy dissipation rate (O'Connor et al., 2010) and spectrum of horizontal wind component (Marques et al., 2017). In these cases during nighttime stable situations the top of the SBL, $P B L H_{\text {Doppler }}^{S B L}$, is detected and under convective situations the $C B L, P B L H_{\text {Doppler }}^{C B L}$, is the one selected.

Based on characteristics of potential temperature profile $(\theta(\mathrm{z})$, where $\mathrm{z}$ is the altitude above the ground) in PBL, some authors (Granados- Muñoz et al., 2012; Wang et al., 2012; Coen et al., 2014) proposed to detect the $P B L H$ from temperature profiles provided by Microwave Radiometer $(M W R)$ data $\left(P B L H_{M W R}\right)$. Cimini et al. (2013) estimated $P B L H_{M W R}$ from brightness temperatures that are directly obtained from $M W R$. An advantage of this kind of systems is that its operation is little affected by rain or cloud covers (Kim et al., 2015). Such characteristics combined with the absence of incomplete overlap issues in the near range allows estimating the $P B L H_{M W R}$ in continuous mode with high recovery rate, so that both unstable (convective) and stable cases are observed, $P B L H_{M W R}^{C B L}$ and $P B L H_{M W R}^{S B L}$ respectively.

According to the previous paragraphs, different remote sensing methods provide complementary information on the PBL structure, with the characterization of its different layers. In this work we check the feasibility of applying $M W R, E L$ and $D L$ for the characterization of the $P B L H$ structure in simple and complex situations. Firstly the $P B L H_{M W R}$ is validated against the $P B L H$ obtained from radiosonde data ( $P B L H_{\text {Radiosonde }}$ ). Then, three study cases and a statistical analysis extended to the experimental period of SLOPE-I campaign are presented in order to show how $D L, E L$ and $M W R$ can offer a picture of the complex $P B L$ dynamics during the whole daily period, i.e., daytime and nighttime. Special care is paid to the limitations of each instrument in the characterization of the $P B L$.

This paper is then organized as follows. The site and the experimental setup are described in section 2. The applied methodologies are introduced in section 3. The analysis of case studies and the statistical comparison are performed in section 4. Conclusions are given in section 5 . 


\subsection{IISTA-CEAMA and SLOPE-I campaign}

114 The measurement campaign was carried out at the Andalusian Institute of Earth System Research (IISTA115 CEAMA). This station is located at the city of Granada, a medium sized non-industrialized city in the 116 Southeastern Spain (Granada, $37.16^{\circ} \mathrm{N}, 3.61^{\circ} \mathrm{W}, 680 \mathrm{~m}$ a.s.1.). Granada is surrounded by mountains and 117 dominated by Mediterranean-continental conditions, which are responsible for large seasonal temperature 118 differences, providing cool winters and hot summers. The most humid period goes from late autumn to 119 early spring. The rest of the year is characterized by rain scarcity. Granada is predominantly affected by 120 aerosol particles coming from Europe and mineral dust particles from the African continent and the heavy 121 traffic along all year (Lyamani et al., 2006a, b, 2010; Córdoba-Jabonero et al, 2011; Titos et al., 2012, 2014; 122 Navas-Guzmán et al., 2013; Valenzuela et al., 2014). Main local sources are road traffic, domestic-heating 123 and biomass burning (mostly in winter time) (Titos et al., 2017). Transported smoke principally from North 124 America, North Africa and the Iberian Peninsula can also affect the study area (Alados-Arboledas et al., 2011; Navas-Guzmán et al., 2013; Preißler et al., 2013; Ortiz-Amezcua et al., 2014, 2017).

126 The field campaign Sierra Nevada Lidar aerOsol Profiling Experiment I (SLOPE I) was held from May to 127 September 2016 in South-Eastern Spain in the framework of the European Research Infrastructure for the 128 observation of Aerosol, Clouds, and Trace gases (ACTRIS). This campaign aimed to perform a closure 129 study by comparing remote sensing system (located at IISTA-CEAMA) and in-situ measurements, which 130 were performed in different heights in the slope of Sierra Nevada at $20 \mathrm{~km}$ away from IISTA-CEAMA.

\subsection{Instrumentation}

132

The biaxial ground-based Elastic-Raman lidar system MULHACEN (customized version of LR331D400,

133 Raymetrics S.A.), is deployed at IISTA-CEAMA and is part of the EARLINET (Pappalardo et al, 2014) 134 and SPALINET (Sicard et al, 2009) networks. MULHACEN operates with a pulsed Nd:YAG laser, 135 frequency doubled and tripled by Potassium Dideuterium Phosphate crystals. It emits at the wavelengths 136355,532 and $1064 \mathrm{~nm}$ with output energies per pulse of 60,65 and $110 \mathrm{~mJ}$, respectively. It has three elastic 137 channels, which are 355, 532 (parallel and perpendicular polarization) and $1064 \mathrm{~nm}$, and three Raman138 shifted channels, which are 387 (from $\mathrm{N}_{2}$ ), 408 (from $\mathrm{H}_{2} \mathrm{O}$ ) and $607 \mathrm{~nm}$ (from $\mathrm{N}_{2}$ ). MULHACEN has a 139 nominal spatial resolution of $7.5 \mathrm{~m}$. The overlap is complete at $90 \%$ between 520 and $820 \mathrm{~m}$ a.g.l. for all 140 the wavelengths and full overlap is reached around $1220 \mathrm{~m}$ a.g.l (Navas-Guzmán et al., 2011; Guerrero141 Rascado et al., 2010). Further technical details are given by Guerrero-Rascado et al. (2008, 2009).

142 The coherent $D L$ (Halo Photonics) model Stream Line is operating in continuous and automatic mode since 143 May 2016. This system uses heterodyne detection to measure the Doppler shift of backscattered light. It 144 operates an eye-safe laser transmitter vertically pointing to zenith emitting at $1.5 \mu \mathrm{m}$ with pulse energy and 145 repetition rate of $100 \mu \mathrm{J}$ and $15 \mathrm{KHz}$, respectively. The $D L$ records the backscattered signal with 300 gates, 

in Stare mode (only the vertical wind speed is measured) with a time resolution of $2 \mathrm{~s}$

The ground-based passive microwave radiometer (RPG-HATPRO G2, Radiometer Physics GmbH) is part of MWRnet (Rose et al., 2005; Caumont et al., 2016). This system operates in automatic and continuous mode since November 2011. It measures the sky brightness temperature with a radiometric resolution between 0.3 and $0.4 \mathrm{~K}$ root mean square error at $1 \mathrm{~s}$ integration time. It operates with direct detection receivers within two bands: $22-31 \mathrm{GHz}$ (water vapor - $\mathrm{K}$ band) and 51-58 GHz (oxygen - $\mathrm{V}$ band), from which ones is possible to derive relative humidity and temperature profiles, respectively. Both profiles are obtained by inversion algorithms described in Rose et al. (2005). The vertical resolution varies between 10 and $200 \mathrm{~m}$ in the first $2 \mathrm{Km}$. From 2 to $10 \mathrm{Km}$, such resolution varies between 200 and $1000 \mathrm{~m}$ (NavasGuzmán et al., 2014).

During this campaign, twenty-three radiosondes were also available, so that nineteen were launched during the convective period (between 17:00 and 18:00 $\mathrm{h}$-local time) and four were launched during stable period (between 21:00 and 22:00 $\mathrm{h}$ - local time). The data were acquired with lightweight weather radiosondes (DFM-06, GRAW Radiosondes), which provides profiles of temperature (resolution $0.01^{\circ} \mathrm{C}$ and accuracy $0.2^{\circ} \mathrm{C}$ ), pressure (resolution $0.1 \mathrm{hPa}$, accuracy $0.5 \mathrm{hPa}$ ), humidity (resolution $1 \%$, accuracy $2 \%$ ) and wind speed (resolution $0.1 \mathrm{~m} / \mathrm{s}$, accuracy $0.2 \mathrm{~m} / \mathrm{s}$ ). Data processing were accomplish by the Grawmet5 software and a GS-E ground station from the same manufacturer (Granados-Muñoz et al., 2012). The surface temperature was obtained from a meteorological station (HMP60, Vaisala), with a temporal resolution of 2 minutes and an accuracy and precision of $0.6^{\circ} \mathrm{C}$ and $0.01^{\circ} \mathrm{C}$, respectively.

\subsection{Temperature Method}

169 The algorithm combines two approaches, namely the Parcel Method (PM) (Holzworth, 1964) and

170 Temperature Gradient Method (TGM) (Coen, 2014), estimating the PBLH from MWR and Radiosonde 171 data $\left(P B L H_{M W R}\right.$ and $P B L H_{\text {Radiosonde, }}$, respectively) under convective $\left(P B L H^{C B L}\right)$ and stable situations $172\left(P B L H^{S B L}\right)$. The discrimination between stable and convective situations is based on the differences in 173 vertical profiles of potential temperature under stable and unstable conditions (see Stull, 1988). Thus we 174 propose a methodology where the surface potential temperature $\left(\theta\left(z_{0}\right)\right.$, which is obtained from the 175 meteorological station co-located with the MWR) is compared with all points in $\theta(\mathrm{z})$ profile below $5 \mathrm{~km}$ 176 a.g.l, where $z_{0}$ and $z$ represent, respectively, the surface and the range of heights above the ground. If all 177 points have values larger than $\theta\left(\mathrm{z}_{0}\right)$, the situation is labelled as stable and TGM is used. Otherwise, the 178 situation is considered as unstable and the PM is applied. The choice of $5 \mathrm{~km}$ guarantees that we check the 179 full range that could cover the PBL at Granada. 
The $P M$ estimates the $P B L H^{C B L}$ at height $(z)$ where $\theta(z)$ is equal to $\theta\left(z_{0}\right)$, because this is the altitude where an air parcel with an ambient temperature $T$ can adiabatically rise from the ground by convection (Holzworth, 1964). The TGM provides the $P B L H^{S B L}$ from two definitions: surface-based temperature inversion (SBTI) (the first height where $T$ increases as function of altitude) and top of stable boundary layer $(T S B L)$ (the first height above $S B T I$ where $d \theta / d z=0$ ), therefore, firstly SBTI is detected from $T(z)$, then from this height is identified the TSBL in the $\theta(z)$. If $S B T I$ or TSBL are not detected the PBLH ${ }^{S B L}$ is labelled as "not identified".

The potential temperature profile used in this algorithm is obtained from the temperature vertical profile, assuming that the surface pressure is $1000 \mathrm{mb}$ and thus using the definition of potential temperature by applying the following formula:

$$
\theta(z)=T(z)+0.0098 * z \quad \text { (1) }(\text { Stull, 2011) }
$$

where $T(z)[\mathrm{K}]$ is the temperature profile, $z$ is the height above the ground level, $0.0098[\mathrm{~K} / \mathrm{m}]$ is the dry adiabatic temperature gradient, and the atmosphere is considered as standard. For the computation of $P B L H_{M W R}$, the profiles of $\theta(z)$ were 30-min averaged in order to reduce the noise, providing 30-min $P B L H$ estimations.

\subsection{Variance threshold method}

The variance of vertical wind speed $\left(\sigma_{w}{ }^{2}\right)$ is used to estimate the vertical size of convective cells growing due to homogeneous turbulent movement. Therefore, this variable is applied as an indicator of the mixing layer height, corresponding to $P B L H_{\text {Doppler }}^{S B L}$ in stable cases and $P B L H_{\text {Doppler }}^{C B L}$ in unstable cases. $P B L H_{\text {Doppler }}$ is adopted as the first height where $\sigma_{w}{ }^{2}$ has a value lower than a predetermined threshold $\left(t h_{v a r}\right)$. Although different studies use distinct $t h_{v a r}$ values ranging from $t h_{v a r}=0.09 \mathrm{~m}^{2} / \mathrm{s}^{2}$ (Pearson et al., 2010) to $0.16 \mathrm{~m}^{2} / \mathrm{s}^{2}$ (Träumner et. al 2009, Schween et al. 2014), Schween et al., 2014 demonstrated that a variation of $25 \%$ in $t h_{v a r}$ value causes a deviation around $7 \%$ in $P B L H$ detection. We adopted the threshold value of $0.16 \mathrm{~m}^{2} / \mathrm{s}^{2}$ that is extendedly used, being obtained from the semi-theoretical profile of $\sigma_{w}$ proposed by Lenschow et al. (1980). This value of $t h_{v a r}$ also was confirmed with Doppler lidar measurements and mathematical modelling by Large Eddy Simulations (LES) (Lenschow et al., 2012). In our case $\sigma_{w}^{2}$ is calculated using time intervals of 30 minutes.

\subsection{Extended Kalman Filter ( $E K F$ ) method}

The Extended Kalman Filter ( $E K F)$ method (Lange et al., 2014; Banks et al. 2016) estimates the $P B L H_{\text {elastic }}$ based on an adaptive approach by extended Kalman Filter, which generates a simplified erflike curve (Gauss error function (Abramowitz and Stegun, 1965)) model $h$ (fig. 1) from the $E L$ range corrected signal $(R C S)$ and four time-adaptive coefficients as follows:

$$
h\left(R ; R_{b l}, d, A, c\right)=\frac{A}{2}\left\{1-\operatorname{erf}\left[\frac{d}{\sqrt{2}}\left(R-R_{b l}\right)\right]\right\}+c
$$


where $R_{b l}$ is an initial guess to $P B L H_{\text {elastic }}, d$ is a scaling factor to entrainment zone thickness, $A$ is the amplitude of the erf transition, and $c$ is the average value of molecular signal (Banks et al. 2016). The successful use of this method strongly depends on the correct initialization of the $E K F$ state vector that requires a priori statistical covariance information. This is obtained from the state vector noise and a priori error covariance matrices. Further details are given by Lange et al., 2014. In this work the RCS profiles of wavelength $532 \mathrm{~nm}$ are utilized. Such profiles were averaged in packages of 30 minutes in order to reduce the noise and provide $P B L H$ estimation with this same time resolution

\subsection{Statistical Parameters}

221

The statistical comparison performed in section 4 is based on following parameters:

222

- Pearson coefficient of correlation $(R)$ : It indicates the level (and direction) of correlation performed between two group of data:

224

226

- Index of agreement $(D)$ (Willmont, 1981): $D$, often applied in comparison of models, presents the The absolute values of $R$ can varies from 0 to 1 , the closer the absolute values of $R$ to 1 , the larger correlation between the analyzed variables. level of agreement between a given set of values $\left(P B L H_{x_{i}}\right)$ and the reference values $\left(\right.$ PBLH $\left._{\text {Reference }}\right)$ :

$$
D=1-\frac{\sum_{i=1}^{n}\left(P B L H_{\text {Reference }_{i}}-P B L H_{x_{i}}\right)^{2}}{\sum_{i=1}^{n}\left(\left|P B L H_{x_{i}}-\overline{P B L H}_{\text {Reference }}\right|-\left|P B L H_{\text {Reference }_{i}}-\overline{P B L H}_{\text {Reference }}\right|\right)^{2}}
$$

$D$ ranges from 0 to 1 , higher values of $D$ indicating better agreement between $P B L H_{\text {Reference }}$ and the $P B L H_{x}$.

- Root Mean Square Error (RMSE): Such variable demonstrates how concentrated the data $\left(P B L H_{x}\right)$ are around the line of the best fit obtained from reference data $\left(P B L H_{\text {Reference }}\right)$ :

$$
R M S E=\sqrt{\frac{\sum_{i=1}^{n}\left(\text { PBLH }_{\text {Reference }_{i}}-\text { PBLH }_{x_{i}}\right)^{2}}{n}}
$$

- Percentage change $\left(\triangle P B L H_{x-\text { Reference }}\right)$ : This variable represents the relative percentage change between $P B L H_{x}$ and the $P B L H_{\text {Reference }}$ :

$$
\triangle P B L H_{x-\text { Reference }}=\frac{P B L H_{x}-P B L H_{\text {Reference }}}{P B L H_{\text {Reference }}}
$$


242 In all equations demonstrated above $P B L H_{x}$ and $\overline{P B L H}_{x}$ represent the $P B L H$ value and its average value

243 respectively, where the subscribed index $x$ indicates the instrument applied in $P B L H$ detection (MWR,

$244 D L\left[\right.$ Doppler] or EL [Elastic]). In the same way $P B L H_{\text {Reference }}$ and $\overline{P B L H}_{\text {Reference }}$ represent the $P B L H$

245 value used as reference and its average value, respectively, so that the subscribed index Reference indicate

246 the instrument used as reference in PBLH detection (MWR or Radiosonde as will be described in section

247 4.1).

$248 \quad 4$ Results

$249 \quad$ 4.1 MWR and radiosonde PBL intercomparison

250 This sub-section presents a statistical comparison of $P B L H$ retrieved from $M W R$ data $\left(P B L H_{M W R}\right)$ and the 251 estimations obtained applying similar methodology (Section 3.1) to the radiosonde profiles $252\left(P B L H_{\text {Radiosonde }}\right) . P B L H_{M W R}$ and $P B L H_{\text {Radiosonde }}$ present very similar results with high level of 253 correlations $(R)$ and index of agreement $(D)$ under convective and stable atmospheric conditions $254\left(R_{\text {Convective }}=0.96, D_{\text {Convective }}=0.89, R_{\text {Stable }}=0.97, D_{\text {Stable }}=0.98\right)$. The percentage difference between $255 P B L H_{M W R}$ and $P B L H_{\text {Radiosonde }}\left(\triangle P B L H_{M W R-R a d i o s o n d e}\right)$ in convective cases (-0.6\%) is smaller than the 256 corresponding relative difference observed in stable cases (8.1\%), when the $M W R$ always overestimate the 257 PBLH derived from the radiosonde. This overestimation probably occurs because of the limited and smaller 258 vertical resolution of $M W R$ in comparison with radiosonde (in the first $350 \mathrm{~m} \theta_{\text {Radiosonde }}(\mathrm{z}$ ) has around 25912 levels, while $\theta_{M W R}(\mathrm{z})$ has 3 levels), what requires further interpolations during the process of $P B L H_{M W R}$ 260 detection. The Root Mean Square Error (RMSE) values observed in both situations are small (190 and 50 $261 \mathrm{~m}$ in convective and stable cases, respectively). The largest value of $R M S E$ occurs under convective 262 conditions because of the average value of PBLH obtained in unstable conditions is around $68 \%$ higher 263 than the average values in stable conditions.

264 Based on these results, we can conclude that, although the vertical temperature profile derived from $M W R$ 265 has lower vertical resolution than that derived from the radiosondes, the values of $P B L H_{M W R}$ obtained by 266 the methodology described in section 3.1 are equivalents to $P B L H_{\text {Radiosonde }}$, retrieved by an equivalent 267 algorithm applied over the radiosonde temperature profiles.

268 As mentioned before, the $P B L H$ detection based on radiosonde data is the most accepted methodology for 269 deriving the $C B L$ and $S B L$. Therefore, due to good agreement between $P B L H_{M W R}$ and $P B L H_{\text {Radiosonde, }}$ 270 and the high temporal resolution of $M W R, P B L H_{M W R}$ is adopted as standard procedure for deriving the 271 height for the $C B L$ and the $S B L$. In this way a continuous $P B L H$ detection is performed thus providing an 272 insight on the $P B L$ dynamics along the day. 
274 As aforementioned in Section 1, the complexity of the $P B L$ characterization is linked to the complexity of 275 its structure that changes along the day. In this section, we present three case studies in increasing level of 276 complexity to analyze how $M W R, E L$ and $D L$ determine the $P B L$ structure under different situations. The 277 three scenarios are: 1) well-defined $P B L$ (the simplest case); 2) presence of clouds (complicated situation 278 mainly for lidar systems, e.g. Hennemuth and Lammert, 2006), and (iii) Saharan dust outbreak (very complicated and typical situation over the city of Granada, e.g., Bravo-Aranda et al., 2017).

\subsubsection{Well-defined PBL case}

281

282

283

284

285

286

287

288

289

290

291

292

293

294

295

296

297

298

299

300

301

302

303

304

305

306

307

A well-defined $P B L$ case was detected on $19^{\text {th }}$ May 2016 with $M W R$ and $D L$ measuring continuously, and MULHACEN operating from 08:20 until 18:00 UTC. Figure 2 shows the temporal evolution of the $E L R C S$ at $532 \mathrm{~nm}$ and the retrieved $P B L H_{M W R}, P B L H_{\text {Doppler }}$ and $P B L H_{\text {elastic }}$. The last one only can be observed after 10:00 UTC, because the $C B L$ was below the full-overlap height of MULHACEN. From 08:20 until 10:00 UTC the RCS temporal evolution suggest the presence of the $R L$ over the $C B L$. Also there are some aerosol layers over the $C B L$ between 13:00 and 18:00 UTC with altitudes around $2.3 \mathrm{~km} \mathrm{a.g.1.}$

Figure 3 presents the temporal evolution of the relative differences in percentage $\triangle P B L H_{D o p p l e r-M W R}$ (blue bars) and $\triangle P B L H_{\text {Elastic-MWR }}$ (orange bars), evaluated in 30-min intervals. Due to the small height for full overlap of the $D L$, it is feasible to perform the comparison between $D L$ and $M W R$ during all the convective period (06:00-18:00 UTC). From the first hours until 15:00 UTC, $\left|\triangle P B L H_{\text {Doppler-MWR }}\right|$ varies between 4 and $8 \%$. The largest values of $\triangle P B L H_{D o p p l e r-M W R}$ (above 10\%) are observed in the last hours when $P B L$ begins to decrease. This is caused by the different $P B L H$ tracers used in each method. Unlike the moments of intense convection where both algorithms detect the height of $C B L\left(P B L H_{M W R}^{C B L} \sim P B L H_{D o p p l e r}^{C B L}\right)$, when $P B L$ stability is changing the variance threshold method detects the $M L$ height, while Temperature method detects the TSBL. Resulting in the higher values of $\triangle P B L H_{D o p p l e r-M W R}$.

When $C B L$ grows or decrease rather fast (10:00-11:30 UTC and 16:00 - 18:00 UTC), high values of $\left|\triangle P B L H_{\text {elastic-MWR }}\right|$ are observed (between 8 and 15\%). Although, in this period, EKF and Temperature methods detect the height of $C B L$, the different tracers used are subject to distinct interferences. While the temperature profile varies directly by thermodynamic phenomena, aerosols are affected by these phenomena and also can be influenced by others like emission rate from the ground and/or inertia, resulting in the differences observed in figure 3. When $C B L$ is fully developed (between 12:00 and 15:30 UTC) its height does not show great differences among different methods, thus, under these conditions, the different tracers agree in the determination of the $P B L H$. Therefore the smaller values of $\triangle P B L H_{M W R-e l a s t i c}$ are detected under fully developed convective columns $(\sim 1 \%)$. This high agreement between $P B L H$ estimated from different tracers when $C B L$ is fully developed was also observed by Schwenn et al. (2014) during the long-term comparisons between $P B L H$ obtained from Doppler lidar and ceilometer data at Forschungszentrum Jülich (Germany). 
The second study case corresponds to $16^{\text {th }}$ May 2016, where measurements with $M W R$ and $D L$ were continually performed while MULHACEN was operated from 10:36 until 16:30 UTC. This situation is more complex than in the previous case, due to presence of clouds between 1.8 and $2.8 \mathrm{~km}$ a.g.1. (12:30 to 16:30 UTC -) and lofted aerosol layers between 2.5 and $3.5 \mathrm{~km}$ a.g.1.. Figure 4 shows the $E L R C S$ temporal evolution together with $P B L H_{\text {elastic }}, P B L H_{M W R}$, and $P B L H_{\text {Doppler }}$.

Figure 5 presents the percentage differences of $\triangle P B L H_{\text {elastic }-M W R}$ and $\triangle P B L H_{\text {Doppler }-M W R}$ for the whole period of measurements. The behavior of $\triangle P B L H_{\text {Doppler-MWR }}$ in this case is similar to that observed in the study case I, small and almost constant values when $C B L$ does not varies too much and large values in the periods when there are intense and fast variation of $P B L H$. During the cloudy periods, $\left|\triangle P B L H_{\text {Doppler }-M W R}\right|$ values increase (around $15 \%$ ), because the $D L$ and Temperature methods to detect the PBLH under cloudy conditions establishes the PBLH at the cloud base (Schween et al., 2014) and at the cloud center, respectively.

In a similar way as $\triangle P B L H_{\text {Doppler }-M W R}, \triangle P B L H_{\text {elastic }-M W R}$ presents a pattern similar to that encountered in the study case I, with values close to $5 \%$ around noon, and values close to $10 \%$ at the moments of high convective activity. High values of $\triangle P B L H_{M W R-e l a s t i c}$ are observed during the cloudy period because, similarly at $D L$ method, $P B L H$ it is established at the cloud base.

\subsubsection{Saharan dust case}

327 This case illustrates the Saharan dust outbreak over Granada on 22 $2^{\text {th }}$ July 2017 detected by $M W R, D L$ and $328 E L$ (from 04:47 until 12:32 UTC). Figure 6 shows the $E L R C S$ temporal evolution together with $P B L H_{M W R}$, $329 P B L H_{\text {Doppler }}$ and $P B L H_{\text {elastic }}$. At the start time of the $E L$ measurement the dust layer is coupled with $R L$.

330 In such cases $P B L H$ detection is very complicated for methods that use the atmospheric aerosol as a tracer, 331 and many of them often overestimate the PBLH. Bravo-Aranda et al. (2017) proposed the utilization of 332 lidar depolarization measurements to distinguish between mineral dust and anthropogenic aerosol layers in 333 order to estimate the height only of the last one and adopt it as PBLH.

$334 P B L H_{\text {Doppler }}$ detection is not affected by presence of dust layer, because it is based on the level of mixing. 335 Although there is a mineral dust layer coupled with other anthropogenic aerosol layers, the level of mixing 336 observed in the first meters of $P B L$ exceeds the threshold selected, therefore $P B L H_{\text {Doppler }}^{C B L}$ is detected at 337 this region. In contrast, the presence of mineral dust layer, due to absorption of infrared radiation, changes 338 the potential temperature profile, so that $P B L H_{M W R}^{C B L}$ is registered in upper layers in comparison with $339 P B L H_{\text {Doppler }}^{C B L}$. These detections of distinct phenomena result in higher values of $\triangle P B L H_{\text {Doppler-MWR }}$ in 340 comparison with the other study cases previously discussed (reaching 60\%). However, the values of 

of measurement (Fig. 7).

343 During the first hours of this measurement, $P B L H_{\text {elastic }}$ probably would be affected by dust layer due to 344 impossibility of differentiating the coupled layers. At 11:00 UTC the dust layer is displaced (Fig. 6) and 345 does not affect the $P B L H_{\text {elastic }}$ detection. Although the fast $P B L$ growth and the existence of different 346 influences acting on the distinct tracers result in high values of $\triangle P B L H_{M W R-e l a s t i c}$ in comparison with other 347 situations (reaching 32\%). However, these values decrease as the growth rate reduces, reaching $11 \%$ in the 348 last hour of measurements. Banks et al. (2015) found similar results when they compared the $P B L H_{\text {elastic }}$ obtained from $E K F$ with $P B L H$ estimated from radiosonde data by bulk Richardson number.

\subsection{Statistical analysis}

351 The statistical study of the comparison of the PBLH retrieved by the three remote sensing methods used 352 during all SLOPE-I campaign is presented in this section. The comparison between $P B L H_{M W R}$ and $353 P B L H_{\text {Doppler }}$ was performed over 24 hours of all days of campaign. This allows the evaluation of the $D L$ retrieval, $P B L H_{\text {Doppler }}$, both under stable and convective situations. Nevertheless, the comparison between $P B L H_{\text {elastic }}$ and $P B L H_{M W R}$ is not extended for the whole day because, as a result of the relatively large full overlap height of MULHACEN, in the morning and at night the $P B L H_{\text {elastic }}^{R L}$ is detected (Bravo-Aranda, 2017), while Temperature method detects the $P B L H_{M W R}^{C B L}$. Therefore, to ensure that both instruments detect the same variable, $E K F$ method was applied only when the reference $P B L H_{M W R}$ exceeded 700 meters a.g.l., therefore between 09:00 and 19:00 UTC

Figure 8 demonstrated the comparison among the average daily $P B L H$ values of $M W R\left(\overline{P B L H}_{M W R}\right), D L$ $\left(\overline{P B L H}_{\text {Doppler }}\right)$ and $E L\left(\overline{P B L H}_{\text {Elastic }}\right)$. Both profiles have similar behaviors with differences smaller than $300 \mathrm{~m}$. $\overline{P B L H}_{\text {Elastic }}$ presents the lowers differences with relation to $\overline{P B L H}_{M W R} \cdot \overline{P B L H}_{\text {Doppler }}$ is overestimated when compared to the reference values along almost the whole profile, however the such values do not exceed the standard deviation of $\overline{P B L H}_{M W R}$.

Figure 9 shows the daily pattern, of the statistics describing the comparison between $P B L H_{M W R}$ and $P B L H_{\text {Doppler }}$, with a temporal resolution of 30 minutes. It is evident that the absolute average value of $\triangle P B L H_{\text {Doppler }-M W R}$ does not exceed 20\%. The higher values are observed between 21:00 and 22:00 UTC, 00:00 and 01:00 UTC, 08:30 and 10:30 UTC, 16:30 and 18:30 UTC. The last two intervals are characterized by intense $P B L H$ changes, thus being justified in the terms argued in the discussion of the study cases. The lowest differences are concentrated in central region of day and in some moments associated to the SBL (around 3\%). Most of the time $P B L H_{\text {Doppler }}$ overestimates the $P B L H_{M W R}$, however the higher values of average $\triangle P B L H_{\text {Doppler-MWR }}$ also occur when $P B L H_{M W R}$, is underestimated by $P B L H_{\text {Doppler }}$. $R M S E$ bears

373 practically constant values during the stable periods (around $100 \mathrm{~m}$ ). The highest values occur between 16:30 and 18:30 UTC (around $450 \mathrm{~m}$ ). $R$ values are larger than 0.70 between 04:30 and 16:30 UTC, and the higher values (0.90) are in the central region of day, when $P B L$ is fully-developed. After 16:30 UTC $R$ 
3770.85 during quite all the period, outside of the period between 22:30 and 00:00 UTC, where $D$ is lower than

378 0.70. Similarly to $R$, the higher values of $D(0.99)$ occur often when $P B L$ is fully-developed.

379 From the combination of the statistics presented in figure 9 it is possible to affirm that $P B L H_{\text {Doppler }}$ has a 380 good agreement with $P B L H_{M W R}$ in $80 \%$ of the daily cycle, so that the lower results are observed between 381 20:00 and 00:00 UTC. This is due to the different $P B L H$ indicator adopted by each method, because while 382 the variance threshold method is based on analysis of turbulence level, Temperature method detects the $383 T S B L$, so that these events do not occur always at same height, meanly when $P B L$ has vertical displacements 384 (in this situation decreasing), as mentioned above.

385 Figure 10 shows the statistics describing the comparison between the daily patterns of $P B L H_{M W R}$ and $386 P B L H_{\text {elastic }}$. During all SLOPE-I campaign the absolute average value of $\left(\triangle P B L H_{\text {Elasic-MWR }}\right)$ does not 387 exceed 15\%. The higher values are detected at 09:00 UTC, between 10:00 and 11:30 UTC, at 17:00 UTC 388 and between 18:30 and 19:00 UTC (around 13\%), where frequently PBLH has fast changes. For all the period, the RMSE has values lower than obtained in the comparison between the retrievals of $P B L H$ by $390 M W R$ and $D L$. This difference in the results of RMSE probably occurs due to larger vertical resolution of $391 E L$. Outside the period between 11:30 and 12:00 UTC and at 17:30 UTC, where $R$ values are lower than 3920.8 , high correlations are observed, mainly in the beginning of measurement and in the central part of the 393 day. $D$ presents a similar behavior with values lower than 0.85 between 11:30 and 12:00 UTC and at 17:30 394 UTC and higher values in the central of day, when PBL is fully-developed.

395 The joint analysis of these statistical variables reveals a good agreement between $P B L H_{M W R}$ and $396 P B L H_{\text {elastic }}$ mainly in the central part of day, when $P B L$ is fully developed and low average values of $397 \triangle P B L H_{\text {Elastic-MWR }}$ together with high values of $R$ and $D$ are observed. The largest discrepancies are 398 observed in moments of intense increase and/or decrease of $P B L H$, due to great change in $P B L$ affecting 399 in a different way the distinct $P B L H$ tracers used in each method, thus leading to discrepancies in the 400 retrieval of the $P B L H$.

\section{Conclusions}

402 This work presents a comparison between $P B L H$ obtained from three remote sensing systems, namely 403 $M W R, E L$ and $D L$, which retrieve this variable using as a proxy the vertical profile of potential temperature, 404 aerosol and vertical wind speed, respectively. The data were acquired during SLOPE-I campaign in 405 Granada (Spain) from May to July in 2016.

406 Firstly the $P B L H_{M W R}$ is validated by $P B L H_{\text {Radiosonde }}$ from the methodology describe in section 3.1. The $407 \quad P B L H$ provided by both instruments are equivalent in stable and convective situations, with high level of 408 correlations and index of agreement $\left(R_{\text {Convective }}=0.96, D_{\text {Convective }}=0.89, R_{\text {Stable }}=0.97, D_{\text {Stable }}=0.98\right)$ 409 and low values of $\triangle P B L H_{M W R-R a d i o s o n d e}(-0.6$ and $8.1 \%$ for convective and stable cases, respectively). 410 This agreement between the data allowed us to use the $P B L H_{M W R}$ as the reference method, for the rest of 411 the study. 

are analyzed in detail in order to investigate the behavior of $P B L H_{D o p p l e r}, P B L H_{\text {elastic }}$ and $P B L H_{M W R}$. In situations where $P B L$ is well defined and the growth rate is not so intense, all methods present small percentage differences ( $\triangle P B L H$ smaller than 5\%). Similar results also were observed by Schween et. al (2014) in its long-term comparison between $P B L H$ estimated from $D L$ and ceilometer, and by Coen et. al (2014) in its comparison between $P B L H$ obtained from $M W R, E L$, radiosonde and wind profiler data.

418 However, under scenarios where $P B L$ grows rapidly, there are presence of clouds and/or dust layers, the

419

420

421

422

423

424

425

426

427

428

429

430

431

432

433

434

435

436

437

438 values of $\triangle P B L H$ increase (differences around $60 \%$ for $D L$ and $35 \%$ for $E L$, with respect to the $M W R$ estimations). Such differences are originated by the distinct influence suffered by each tracer (inertia, gravitation, etc.), as well as, $P B L H$ definition (case with presence of clouds).

In addition, a statistical analysis was performed for all SLOPE-I campaign. The comparison between $P B L H_{M W R}$ and $P B L H_{\text {Doppler }}$ is performed over the whole $24 \mathrm{~h}$ day period, while $P B L H_{\text {elastic }}$ and $P B L H_{M W R}$ were compared between 09:00 UTC and 19:00 UTC, due to the shortcomings associated to the rather large height for full overlap of the MULHACEN lidar system. The best agreement between $P B L H_{\text {Doppler }}$ and $P B L H_{M W R}$ (low values of average $\triangle P B L H$ and higher values of $R$ and $D$ ) are obtained when PBL is fully developed. The worst correlations (low values of $R$ and $D$ and higher average values of $\triangle P B L H)$ occur between 21:30 and 00:00 UTC. In the same ways as $P B L H_{\text {Doppler }}, P B L H_{\text {elastic }}$ has the best correlations with $P B L H_{M W R}$ in the central region of day and the worst results in moments of fast $P B L H$ growth and/or decreasing $(R<0.8$ and $D<0.85)$. From these comparison we can conclude that when $P B L$ is full-developed both lidar systems have good results, although $R M S E_{\text {Elastic }}<R M S E_{\text {Doppler }}$ likely as a result of the best vertical resolution of the MULHACEN lidar in comparison with the $D L$. During the periods of intense $P B L H$ increasing and/or reduction $P B L H_{\text {Doppler }}$ has correlations $(D$ always larger than 0.85) better than $P B L H_{\text {Elastic }}$. In stable cases $P B L H_{\text {Doppler }}$ has more reliable values only from 00:30 UTC.

Therefore, although both lidar systems can estimate the $P B L H$ with considerable level of agreement in relation to the reference method $(M W R), E L$ provides better results during the period when $P B L H$ is above its overlap limit, except situations of coupled dust layers are present. On the other hand, $D L$, due to its full overlap at low level, can estimates the $S B L$ during most of the night with high accuracy.

This study demonstrated the feasibility of both algorithms to estimate $P B L H$ in simple and complex situations, as well as the level of reliability of each one during the different phases of $P B L$ daily cycle. Considering that the different techniques demonstrated in this work are complementary, in the future we will intend to use them synergistically in order to provide a detailed detection of the complex $P B L$ structure $(R L, S B L$ and $C B L)$.

\section{Acknowledgements}

This work was supported by the Andalusia Regional Government through project P12-RNM-2409, by the Spanish Ministry of Economy and Competitiveness through project CGL2013-45410-R, CGL2016-81092$\mathrm{R}$ and by the University of Granada through "Plan Propio. Programa 9 Convocatoria 2013. The financial 
support for EARLINET in the ACTRIS Research Infrastructure Project by the European Union's Horizon 2020 research and innovation program through project ACTRIS-2 (grant agreement No 654109). The grant for PhD studies in Colombia, COLCIENCIAS (Doctorado Nacional - 647) associated to the Physics Sciences program at Universidad Nacional de Colombia, Sede Medellín and Asocaicion Universitaria Iberoamericana de Postgrado (AUIP). The authors thankfully acknowledge the FEDER program for the instrumentation used in this work.

\section{References}

Abramowitz, M., Stegun, I.A., 1965. Handbook of Mathematical Functions, Dover, New York.

Alados-Arboledas, L., Müller, D., Guerrero-Rascado, J., Navas-Guzmán, F., Pérez-Ramírez, D., Olmo, F., 2011. Optical and microphysical properties of fresh biomass burning aerosol retrieved by Raman lidar, and star-and sun-photometry. Geophys. Res.Lett. 38, L01807, doi: 10.1029/2010GL045999.

Avoloio, E., Federico, S., Miglietta, M.M., Lo Feudo, T., Calidonna, C. R., Sempreviva, A. M., 2017. Sensitivity analysis of WRF model PBL schemes in simulating boundary-layer variables in southern Italy: An experimental campaign. Atmos. Res., 192, 58-71.

Baars, H., Ansmann, A., Engelmann, R., Althausen, D., 2008. Continuous monitoring of the boundarylayer top with lidar. Atmos. Chem. Phys., 8(3), 10749-10790. http://doi.org/10.5194/acpd-8-10749-2008.

Banks, R. F., Tiana-Alsina, J., Rocadenbosch, F., Baldasano, J. M., 2015. Performance Evaluation of the Boundary-Layer Height from Lidar and the Weather Research and Forecasting Model at an Urban Coastal Site in the North-East Iberian Peninsul. Bound-Lay. Meteorol., 157, 265-292.

Banks, R. F., Baldasano, J. M., 2016. Impact of WRF model PBL schemes on air quality simulations over Catalonia, Spain. Sci. Total Environ., 572, 98-113, http://doi.org/10.1016/j.scitotenv.2016.07.167.

Barlow, J. F., Dunbar, T. M., Nemitz, E. G., Wood, C. R., Gallagher, M. W., Davies, F., O’Connor, E., Harrison, R. M., 2011. Boundary layer dynamics over London, UK, as observed using Doppler lidar during REPARTEE-II. Atmos. Chem. Phys., v. 11, n. 5, p. 2111-2125.

Bravo-aranda, J. A., Moreira, G. de A., Navas-Guzmán, F., Granados-Muñoz, M. J., Guerrero-Rascado, J. L., Pozo-Vázquez, D., Arbizu-Barrena, C., 2017. A new methodology for PBL height estimations based on lidar depolarization measurements : analysis and comparison against MWR and WRF model-based results. Atmos. Chem. Phys., 17, 6839-6851. https://doi.org/10.5194/acp-17-6839-201.

Brooks, I. M., 2003. Finding Boundary Layer Top: Application of a Wavelet Covariance Transform to Lidar Backscatter Profiles. J. Atmos. Ocean. Tech., 20(8), 1092-1105. http://doi.org/10.1175/15200426(2003)020<1092:FBLTAO>2.0.CO.

Caumont, O., Cimini, D., Löhnert, U., Alados-Arboledas, L., Bleisch, R., Buffa, F., Ferrario, M. E., Haefele, A., Huet, T., Madonna, F., Pace, G., 2016. Assimilation of humidity and temperature observations 
retrieved from ground-based microwave radiometers into a convective-scale NWP model. Q. J. Roy. Meteor. Soc., 142 (700), pp. 2692-2704.

Cimini, D., Angelis, F. de, Dupont, J.-C., Pal, S., Haeffelin, M., 2013. Mixing layer height retrievals by multichannel microwave radiometer observations. Atmos. Meas. Tech., 6, 2941-2951. http://doi.org/10.5194/amt-6-2941-2013.

Coen, M. C., Praz, C., Haefele, A., Ruffieux, D., Kaufmann, P.,Calpini, B., 2014. Determination and climatology of the planetary boundary layer height above the Swiss plateau by in situ and remote sensing measurements as well as by the COSMO-2 model. Atmos. Chem. Phys., 14, 13205-13221. https://doi.org/10.5194/acp-14-13205-2014.

Córdoba-Jabonero, C., Sorribas, M., Guerrero-Rascado, J. L., Adame, J. A., Hernández, Y., Lyamani, H., Cachorro, V., Gil, M., Alados-Arboledas, L., Cuevas, E., De La Morena, B., 2011. Synergetic monitoring of Saharan dust plumes and potential impact on surface: A case study of dust transport from Canary Islands to Iberian Peninsula. Atmos. Chem. Phys., 11, 7, 3067-3091.

Das, S. K., Das, S. S., Saha, K., Krishna, U. V. M., Dani, K. K., 2018. Investigation of Kelvin-Helmholtz Instability in the boundary layer using Doppler lidar and radiosonde data. Atmos. Res., 202, 105-111.

Davis, K. J., Gamage, N., Hagelberg, C. R., Kiemle, C., Lenschow, D. H., Sullivan, P. P, 2000. An Objective Method for Deriving Atmospheric Structure from Airborne Lidar Observations. J. Atmos. Ocean. Tech., 17(11), 1455-1468. http://doi.org/10.1175/1520-0426(2000)017<1455:AOMFDA>2.0.CO.

De Tomasi, F., Miglietta, M. M., Perrone, M. R., 2011. The Growth of the Planetary Boundary Layer at a Coastal Site: a Case Study. Bound-Lay. Meteorol., 139(3), 521-541. http://doi.org/10.1007/s10546-0119592-6.

Deardorff, J. W., Willis, G. E., Stockton, B. H., 1980. Laboratory studies of the entrainment zone of a convectively mixed layer. J. Fluid. Mech., 100, 41-64.

Di Giuseppe, F., Riccio, A., Caporaso, L., Bonafé, G., Gobbi, G. P., Angelini, F., 2012. Automatic detection of atmospheric boundary layer height using ceilometer backscatter data assisted by a boundary layer model. Q. J. Roy. Meteor. Soc., 138, 649-663. https://doi.org/10.1002/qj.964.

Eresmaa, N., Karppinen, A., Jofre, S. M., Räsänen, J. V., Talvitie, H., 2006. Mixing height determination by ceilometer. Atmos. Chem. Phys., 6, 1485-1493, https://doi.org/10.5194/acp-6-1485-2006.

Fedele, F., Miglietta, M. M., Perrone, M. R., Burlizzi, P., Bellotti, R., Conte, D., Carducci, A. G. C., 2015. Numerical simulations with the WRF model of water vapour vertical profiles: A comparison with LIDAR and radiosounding measurements. Atmos. Res., 166, 110-119. 
513 Flamant, C., Pelon, J., Flamant, P. H., Durand, P., 1997. Lidar determination of the entrainment zone 514 thickness at the top of the unstable marine atmospheric boundary layer. Bound-Lay. Meteorol., 83, 247515 284, doi:10.1023/A:1000258318944.

516 Granados-Muñoz, M. J., Navas-Guzmán, F., Bravo-Aranda, J. A., Guerrero-Rascado, J. L., Lyamani, H., 517 Fernández-Gálvez, J., Alados-Arboledas, L., 2012. Automatic determination of the planetary boundary 518 layer height using lidar: One-year analysis over southeastern Spain. J. Geophys. Res-Atmos., 117, D18208, 519 https://doi.org/10.1029/2012JD017524.

520 Guerrero-Rascado, J. L., Ruiz, B., Alados-Arboledas, L., 2008. Multi-spectral Lidar characterization of the 521 vertical structure of Saharan dust aerosol over southern Spain. Atmos. Environ., 42, 11, 2668-268.

522 Guerrero-Rascado, J. L., Olmo, F. J., Avilés-Rodríguez, I., Navas-Guzmán, F., Pérez-Ramírez, D., 523 Lyamani, H., Alados-Arboledas, L., 2009. Extreme saharan dust event over the southern Iberian peninsula 524 in September 2007: Active and passive remote sensing from surface and satellite. Atmos. Chem. Phys., 9, $52521,8453-8469$.

526 Guerrero-Rascado, J. L., Costa, M. J., Bortoli, D., Silva, A. M., Lyamani, H., Alados-Arboledas, L., 2010. 527 Infrared lidar overlap function: An experimental determination. Opt. Express, 18, 19, 20350-20359.

528 Haeffelin, M., Angelini, F., Morille, Y., Martucci, G., Frey, S., Gobbi, G. P., Lolli, S., O’Dowd, C. 529 D., Sauvage, L., Xueref-Rémy, Wastine, B., Feist, D. G., 2017. Evaluation of mixing-height retrievals 530 from automatic profiling lidars and ceilometers in view of future integrated networks in Europe. 531 Bound-Lay. Meteorol., 143, 49-75. https://doi.org/10.1007/s10546-011-9643-z.

532 Haman, C. L., Lefer, B., Morris, G. A., 2012. Seasonal variability in the diurnal evolution of the boundary 533 layer in a Near-Coastal: Urban environment. J. Atmos. Ocean. Tech., 29(5), 697-710. 534 https://doi.org/10.1175/JTECH-D-11-00114.1.

535 Hennemuth, B., Lammert, A., 2006. Determination of the atmospheric boundary layer height from 536 radiosonde and lidar backscatter. Bound-Lay. Meteorol., 120, 181 - 200. https://doi.org/ 10.1007/s10546$537 \quad 005-9035-3$.

538 He, Q. S., Mao, J. T., Chen, J. Y., Hu, Y. Y., 2006. Observational and modeling studies of urban 539 atmospheric boundary-layer height and its evolution mechanisms. Atmos. Environ., 40(6), $1064-1077$. 540 https://doi.org/10.1016/j.atmosenv.2005.11.016.

541 Holzworth, C. G., 1964. Estimates of mean maximum mixing depths in the contiguous United States. Mon. 542 Weather Rev., 92, 235-242.

543 Hooper, W. P., Eloranta, E. W., 1986. Lidar measurements of wind in the planetary boundary layer: the 544 method, accuracy, and results from joint measurements with radiosonde and kytoon, J. Appl. Meteorol. 545 Clim., 25, 990-1001. 

precipitation events from microwave radiometer, radiosonde and wind profiler observations. Meteorol.

548 Appl., 22(3), 599-609. https://doi.org/10.1002/met.1494.

549 Korhonen, K., Giannakaki, E., Mielonen, T., Pfüller, A., Laakso, L., Vakkari, V., Baars, H., Engelmann, 550 R., Beukes, J. P., Van Zyl, P. G., Ramandh, A., Ntsangwane, L., Josipovic, M., Tiitta, P., Fourie, G., 551 Ngwana, I., Chiloane, K., Komppula, M., 2014. Atmospheric boundary layer top height in South Africa: 552 measurements with lidar and radiosonde compared to three atmospheric models. Atmos. Chem. Phys., 14(8), 4263-4278. https://doi.org/10.5194/acp-14-4263-2014.

Kovalev, A. V., Eichinger, E. W., 2004. Elastic Lidar: Theory, Practice and Analysis Methods. Willey Interscience.

556 Lange, D., Tiana-alsina, J., Saeed, U., Tomás, S., Rocadenbosch, F., 2014. Using a Kalman Filter and 557 Backscatter Lidar Returns. IEEE T. Geosci. Remote, 52(8), 4717-4728.

558 Lenschow, D. H., Wyngaard, J. C., Pennell, W. T., 1980. Mean Field and Second-Moment Budgets in a 559 Baroclinic, Convective Boundary Layer. J. Atmos. Sci., 37, 1313-1326, doi:10.1175/15200469(1980)0372.0.CO;2.

Lenschow, D., Lothon, M., Mayor, S., Sullivan, P., Canut, G., 2012. A Comparison of Higher-Order

562 Vertical Velocity Moments in the Convective Boundary Layer from Lidar with In Situ Measurements and 563 Large-Eddy Simulation. Bound-Lay. Meteorol., 143, 107-123, doi:10.1007/s10546-011-9615-3. methods of daytime convective boundary layer height based on lidar data. J. Geophys. Res-Atmos., 122, 4578-4593, http://doi.org/10.1002/2016JD025620.

Liu, B., Ma, Y., Gong, W., Zhang, M., Yang, J., 2018. Determination of boundary layer top on the basis of the characteristics of atmospheric particles. Atmos. Environ., 178, 140 - 147.

569 Lyamani, H., Olmo, F. J., Alcántara, A., Alados-Arboledas, L., 2006a. Atmospheric aerosols during the 5702003 heat wave in southeastern Spain I: Spectral optical depth. Atmos. Environ., 40, 6453-6464.

571 Lyamani, H., Olmo, F. J., Alcántara, A., and Alados-Arboledas, L., 2006b. Atmospheric aerosols during 572 the 2003 heat wave in southeastern Spain II: microphysical columnar properties and radiative forcing. 573 Atmos. Environ., 40, 6465-6476.

574 Lyamani, H., Olmo, F. J., Alados-Arboledas, L., 2010. Physical and optical properties of aerosols over an 575 urban location in Spain: seasonal and diurnal variability. Atmos. Chem. Phys., 10, 239-254, 576 doi:10.5194/acp-10-239-2010, 2010.

577 Lopes, F. J. S., Moreira, G. A., Rodrigues, P. F., Guerrero-Rascado, J. L., Andrade, M. F., Landulfo, E., 578 2014. Comparison between two algorithms based on different wavelets to obtain the planetary boundary 579 layer height, Proc. SPIE 9246, Lidar Technologies, Techniques, and Measurements for Atmospheric Remote Sensing X, 92460H, doi: 10.1117/12.2067352. 

complexo para aplicaçoes em energia eolica e impacto ambiental de instalaçoes nucleares. Dissertation

583 (Master in Science). Institute of Research and Nuclear Energy, University of São Paulo.

584 Martucci, G., Matthey, R., Mitev, V., Richner, H., 2007 Comparison between Backscatter Lidar and 585 Radiosonde Measurements of the Diurnal and Nocturnal Stratification in the Lower Troposphere. J. Atmos. 586 Ocean. Tech., 24(7), 1231-1244. http://doi.org/10.1175/JTECH2036.1.

587 Melfi, S. H., Spinhirne J. D., Chou, S. H., Palm, S. P., 1985. Lidar observations of vertically organized 588 convection in the planetary boundary layer over the ocean. J. Appl. Meteorol. Clim., 24(8):806-821.

589 Menut, L., Flamant, C., Pelon, J., Flamant, P. H., 1999. Urban boundary layer height determination from 590 lidar measurements over the Paris area. Appl. Opt., 38, 945-954.

591 Münkel, C., Eresmaa, N., Räsänen, J., Karppinene, A., 2007. Retrieval of mixing height and dust 592 concentration with lidar ceilometer. Bound-Lay. Meteorol., 124,117-128. comparison. Óptica Pura y Aplicada, 48, 179-183. 761-775. http://doi.org/10.1175/JTECH2008.1.

Navas-Guzmán, F., Guerrero-Rascado, J. L., Alados-Arboledas, L., 2011. Retrieval of the lidar overlap function using Raman signals. Óptica Pura y Aplicada, 44, 71-75.

601 Navas-Guzmán, F., Bravo-Aranda, J.A., Guerrero-Rascado, J.L, Granados-Muñoz, M.J, and Alados602 Arboledas, L., 2013. Statistical analysis of aerosol optical properties retrieved by Raman lidar over 603 Southeastern Spain. Tellus B, 65, 21234.

604 Navas-Guzmán, F., Fernández-Gálvez, J., Granados-Muñoz, M. J., Guerrero-Rascado, J. L., Bravo-Aranda, 605 J. A., Alados-Arboledas, L., 2014. Tropospheric water vapor and relative humidity profiles from lidar and 606 microwave radiometry. Atmos. Meas. Tech., 7, 1201-1211.

607 O'Connor, E. J., Illingworth, A. J., Brooks, I. M., Westbrook, C. D., Hogan, R. J., Davies, F., Brooks, A. 608 B. J., 2010. A method for estimating the turbulent kinetic energy dissipation rate from a vertically pointing 609 doppler lidar, and independent evaluation from balloon-borne in situ measurements. J. Atmos. Ocean. 610 Tech., 27, 10, 1652-1664.

611 Ortiz-Amezcua, P., Guerrero-Rascado, J. L., Granados-Muñoz, M. J., Bravo-Aranda, J. A., Alados612 Arboledas, L., 2014. Characterization of atmospheric aerosols for a long range transport of biomass burning 613 particles from canadian forest fires over the southern Iberian peninsula in July 2013. Optica Pura y 614 Aplicada, 47(1), 43-49. 

convective boundary layer and investigation of related statistics. Ann. Geophy., 28(3), 825-847. http://doi.org/10.5194/angeo-28-825-2010.

Pal, S., Haeffelin, M., Batchvarova, E., 2013. Exploring a geophysical process-based attribution technique for the determination of the atmospheric boundary layer depth using aerosol lidar and near-surface meteorological measurements. https://doi.org/10.1002/jgrd.50710.

Pal, S., Haeffelin, M., 2015. Forcing mechanisms governing diurnal, seasonal, and interannual variability in the boundary layer depths: Five years of continuous lidar observations over a suburban site near Paris. J. Geophys. Res-Atmos., 120, 11,936-11,956, doi:10.1002/2015JD023268.

630 Bösenberg, J., D'Amico, G., Mattis, I., Mona, L., Wandinger, U., Amiridis, V., Alados-Arboledas, L., 631 Nicolae, D., Wiegner, M., 2014. EARLINET: towards an advanced sustainable European aerosol lidar network. Atmos. Meas. Tech., 7, 2389-2409, doi:10.5194/amt-7-2389-2014.

633 Pearson, G., Davies, F., Collier, G., 2010. Remote sensing of the tropical rain forest boundary layer using 634 pulsed Doppler lidar. Atmos. Chem. Phys., 10, 5891-5901, doi:10.5194/acp-10-5891- 2010. layers observed over Portugal by lidar. J. Geophys. Res., Volume 118, Issue 9, 16, 3676-3686.

637 Rose, T., Creewll, S., Löhnert, U., Simmer, C., 2005 A network suitable microwave radiometer for 638 operational monitoring of cloudy atmosphere. Atmos. Res., 75, 3, 183 - 200. and Doppler lidar: from case studies to long-term assessment. Atmos. Meas. Tech., 7, 11, p. 3685-3704.

641 Seidel, D. J., Ao, C. O., Li, K., 2010. Estimating climatological planeratry boundary layer heights from 642 radiosonde observations: Comparison of methods and uncertainty analysis. J. Geophys. Res., 115, D16113, 643 doi:10.1029/2009JD013680.

644 Shukla, K. K., Phanikumar, D. V., Newsom, R. K., Kumar, N., Ratnam, V., Naja, M., Singh, N., 2014. 645 Estimation of the mixing layer height over a high altitude site in Cebtrak Himalayan region by using 646 Doppler lidar. J. Atmos. Sol-Terr. Phy., 109, 48-53.

647 Sicard, M., Molero, F., Guerrero-Rascado, J. L., Pedros, R., Exposito, F. J., Cordoba-Jabonero, C., 648 Bolarin, J. M., Comeron, A., Rocadenbosch, F., Pujadas, M., Alados-Arboledas, L., Martinez-Lozano, J. 649 A., Diaz, J. P., Gil, M., Requena, A., Navas-Guzman, F., Moreno, J. M., 2009. Aerosol lidar 

IEEE T. Geosci. Remote, 47, 10, 3547-3559.

Stull, R. B., 1988. An Introduction to Boundary Layer Meteorology, vol. 13, Kluwer Academic Publishers, the Netherlands, Dordrecht/Boston/London.

Stull, R. B., 2011. Meteorology for Scientists and Engineers, $3^{\text {rd }}$ Edition, Uni. Of British Columbia.

655

656

657

658

659

660

661

662

663

664

665

666

667

668

669

670

671

672

673

674

675

676

677

678

679

680

681

682

Titos, G., Foyo-Moreno, I., Lyamani, H., Querol, X., Alastuey, A., Alados-Arboledas, L., 2012. Optical properties and chemical composition of aerosol particles at an urban location: An estimation of the aerosol mass scattering and absorption efficiencies. J. Geophys. Res-Atmos., 117, D04206, doi:10.1029/2011JD016671.

Titos, G., Lyamani, H., Pandolfi, M., Alastuey, A., Alados-Arboledas, L., 2014. Identification of fine (PM1) and coarse (PM10-1) sources of particulate matter in an urban environment. Atmos. Environ., 89, 593-602, 2014

Titos, G., del Águila A., Cazorla, A., Lyamani, H., Casquero-Vera, J. A., Colombi, C., Cuccia, E., Gianelle, V., Alastuey, A., Alasdos-Arboledas, L., 2017. Spatial and temporal variability of carbonaceous aerosols: assessing the impact of biomass burning in the urban environment. Sci. Total Environ., 578, 613-625.

Träumner, K., Kottmeier, C., Corsmeier, U., Wieser, A., 2011. Convective Boundary-Layer Entrainment: Short Review and Progress using Doppler Lidar. Bound-Lay. Meteorol., 141, 369- 391, doi:10.1007/s10546-011-9657-6, 2011.

Valenzuela, A., Olmo, F. J., Lyamani, H., Granados-Muñoz, M. J., Antón, M., Guerrero-Rascado, J. L., Quirantes, A., Toledano, C., Perez-Ramírez, D., Alados-Arboledas, L., 2014. Aerosol transport over the western mediterranean basin: Evidence of the contribution of fine particles to desert dust plumes over alborán island. J. Geophys. Res., 119, 24, 14,028-14,044.

Wang, Z., Cao, X., Zhang, L., Notholt, J., Zhou, B., Liu, R., Zhang, B., 2012. Lidar measurement of planetary boundary layer height and comparison with microwave profiling radiometer observation. Atmo. Meas. Tech., 5(8), 1965-1972.

Wilmont, C. J., 1981. On the validation of models. Phys. Geogr., 2, 184-194.

Zhu, X., Tang, G., Lv, F., Hu, B., Cheng, M., Münkel, C., Schäfer, K., Xin, J., An, X., Wang, G., Li, X., Wang, Y., 2018. The spatial representativeness of mixing layer height observations in the North China Plain. Atmos. Res., 209, 204-211. 


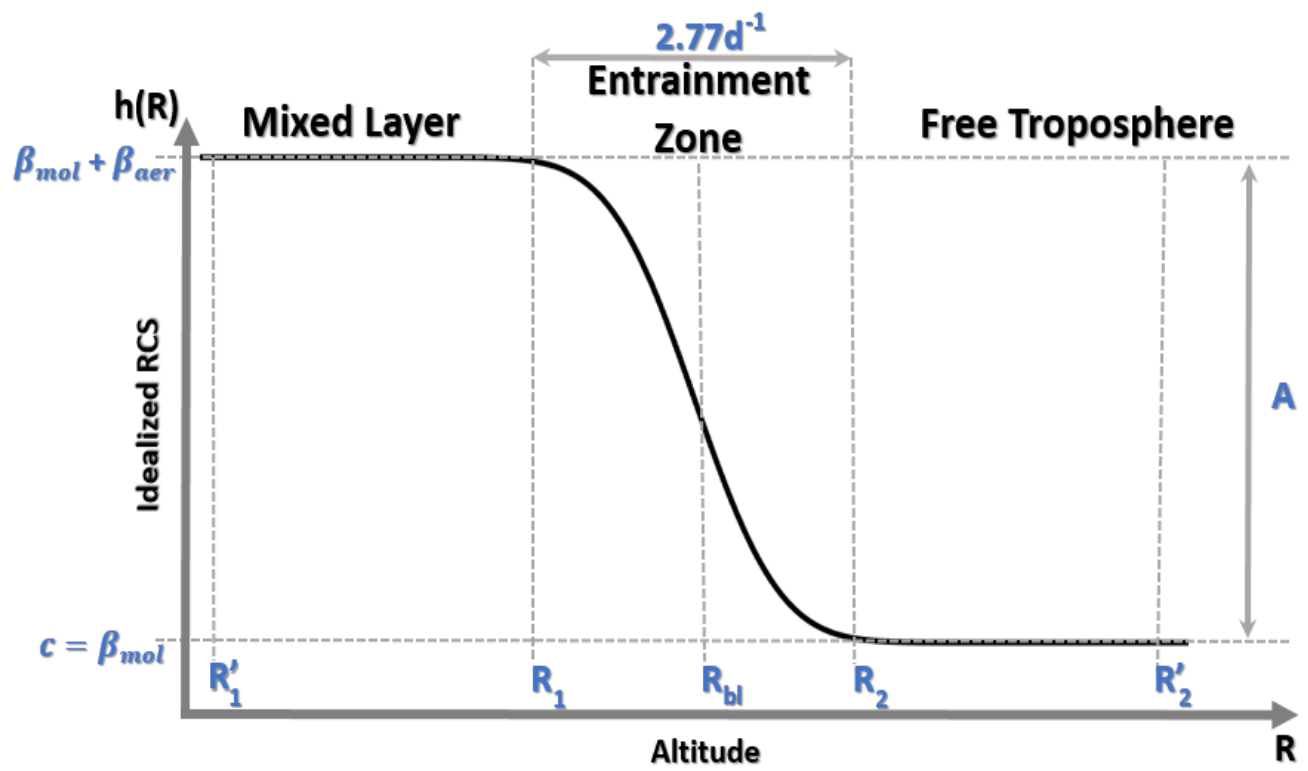

Figure 1- Idealized lidar profile. The pair $R_{1}^{\prime}$ and $R_{2}^{\prime}$ defines the length limit of the observation vector applied in the filter. $R_{1}$ and $R_{2}$ represent the limits of the erf-like PBL transition zone. $R_{b l}$ is the PBLH guest, $\beta_{m o l}$ is the average value of molecular signal, $\beta_{a e r}$ is the signal obtained from aerosol backscattering, $\mathrm{d}$ is a scaling factor to entrainment zone thickness and $A$ is the amplitude of the erf transition.

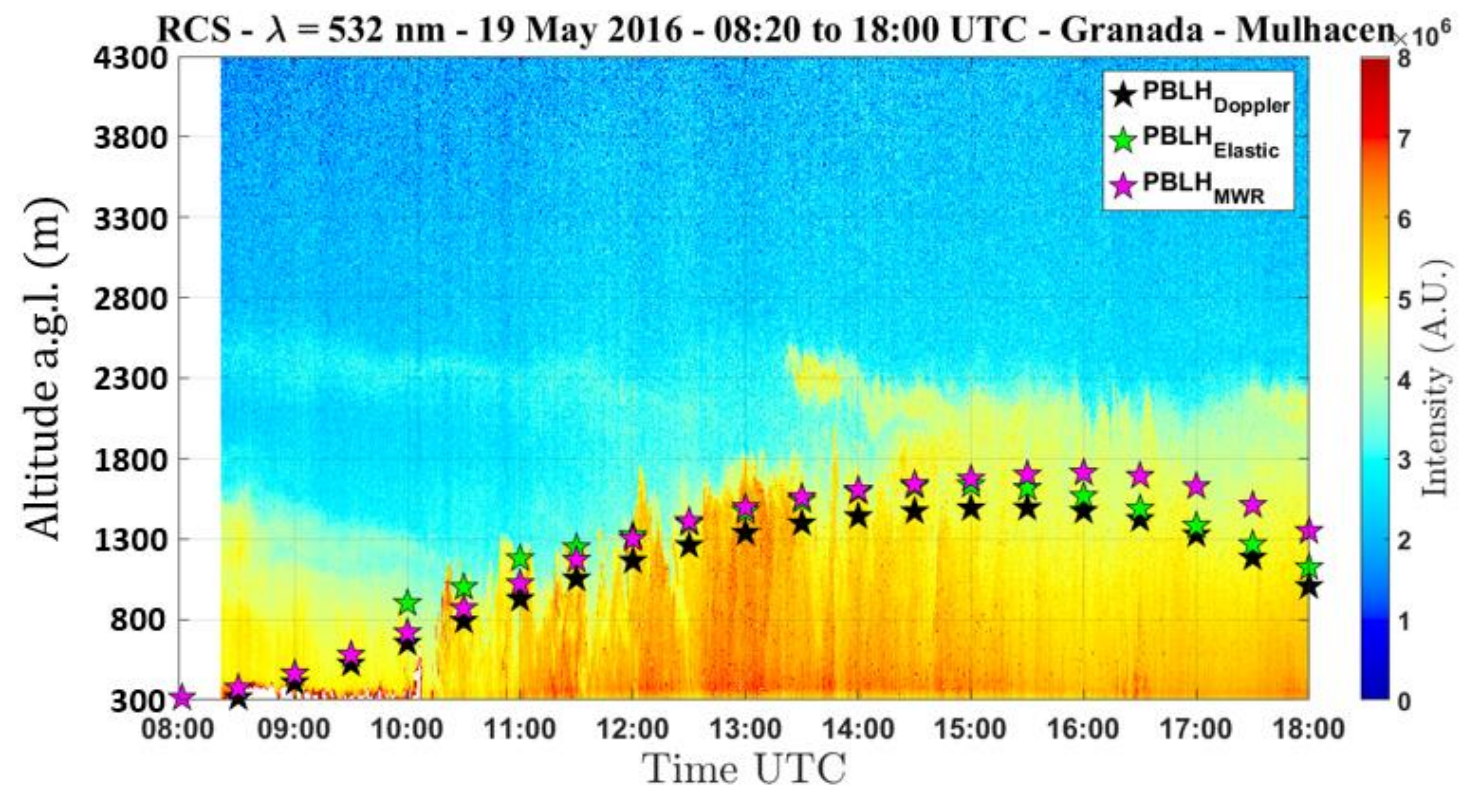

696 


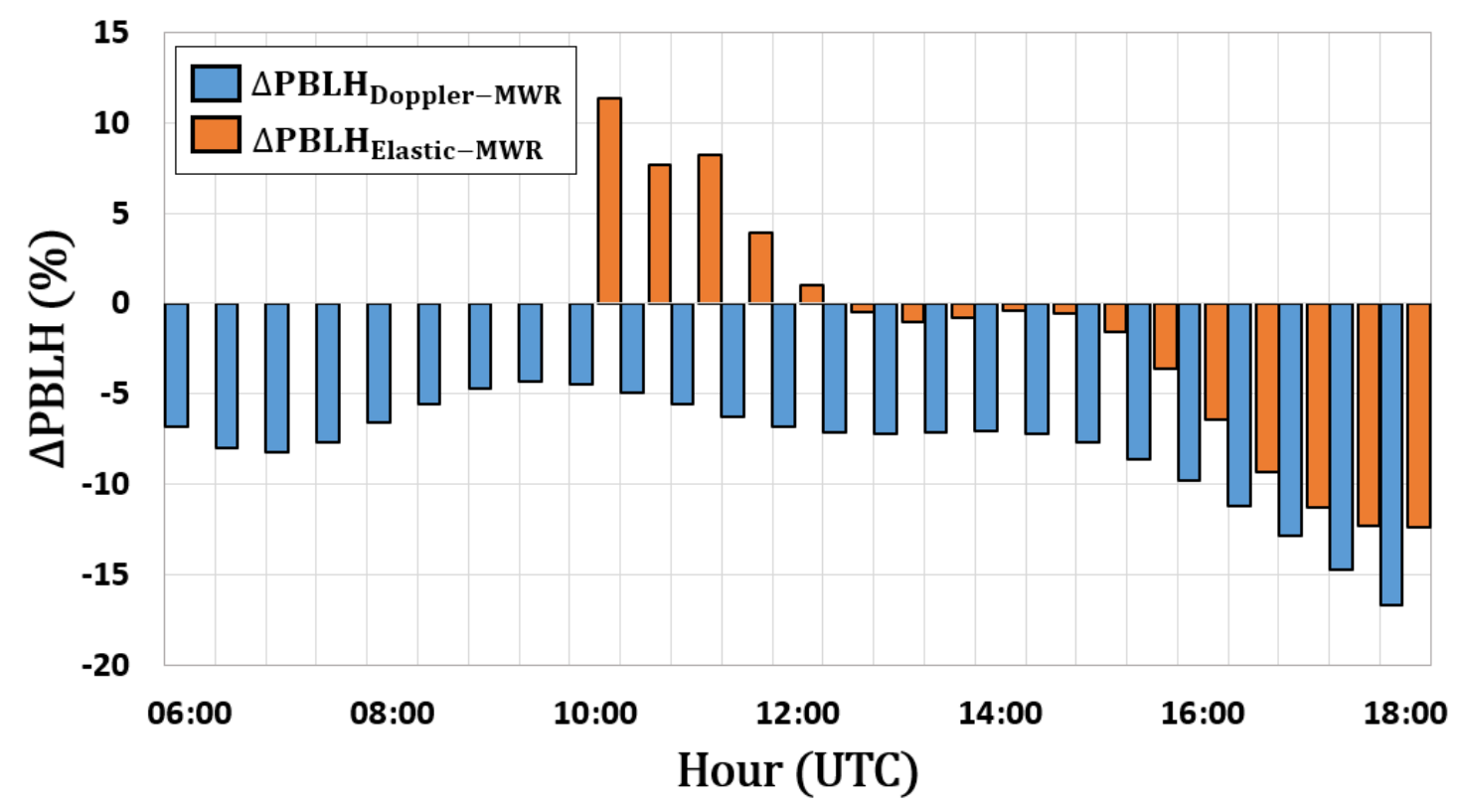

Figure 3 - Temporal evolution of $\triangle P B L H_{\text {Doppler }-M W R}$ (blue bars) and $\triangle P B L H_{\text {Elastic-MWR }}$ (orange bars).

701

702

703

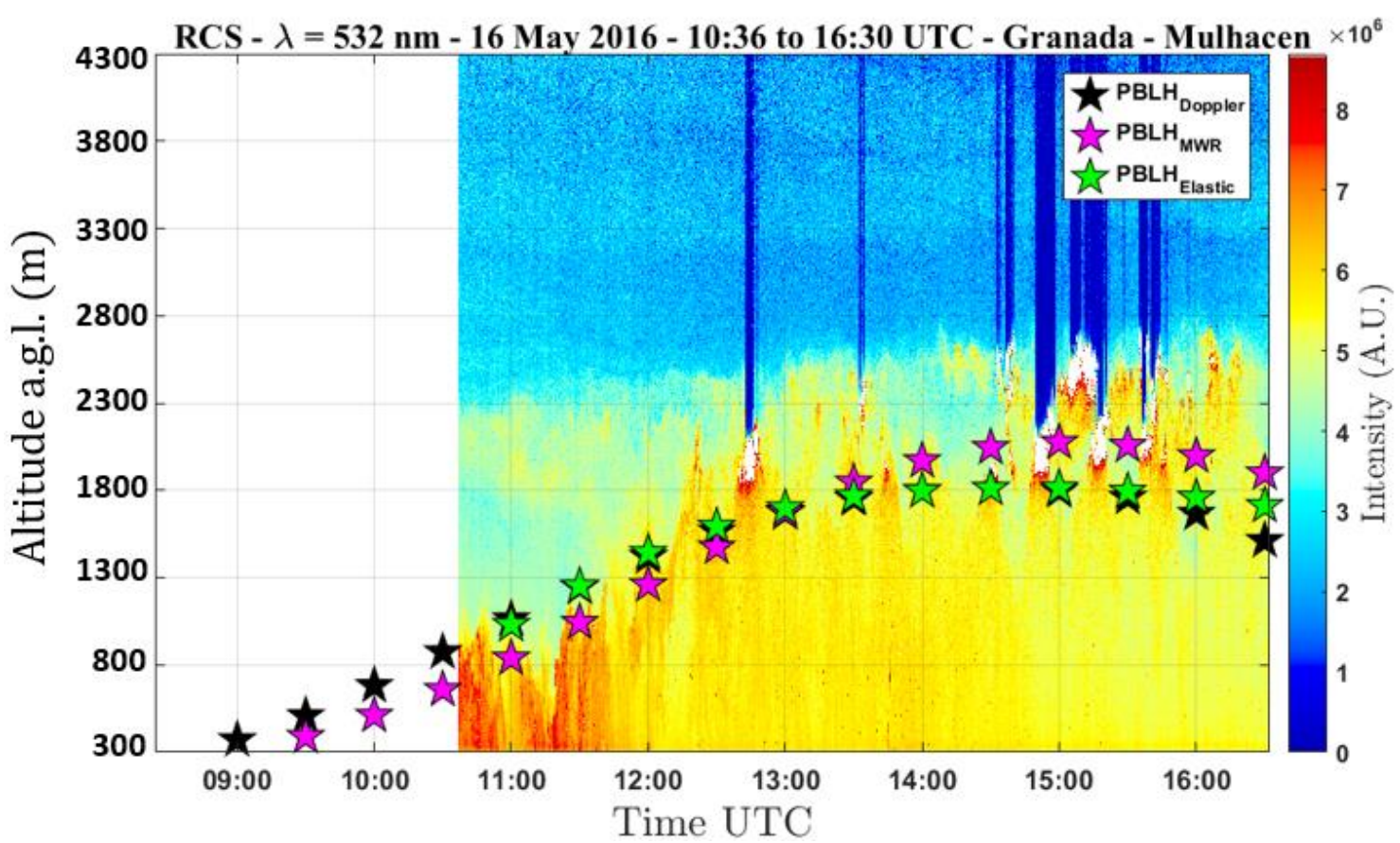

Figure 4 - Temporal evolution of RCS profile and $P B L H$ provided by $M W R$ (pink stars), EL (green stars) and $D L$ (black stars). 


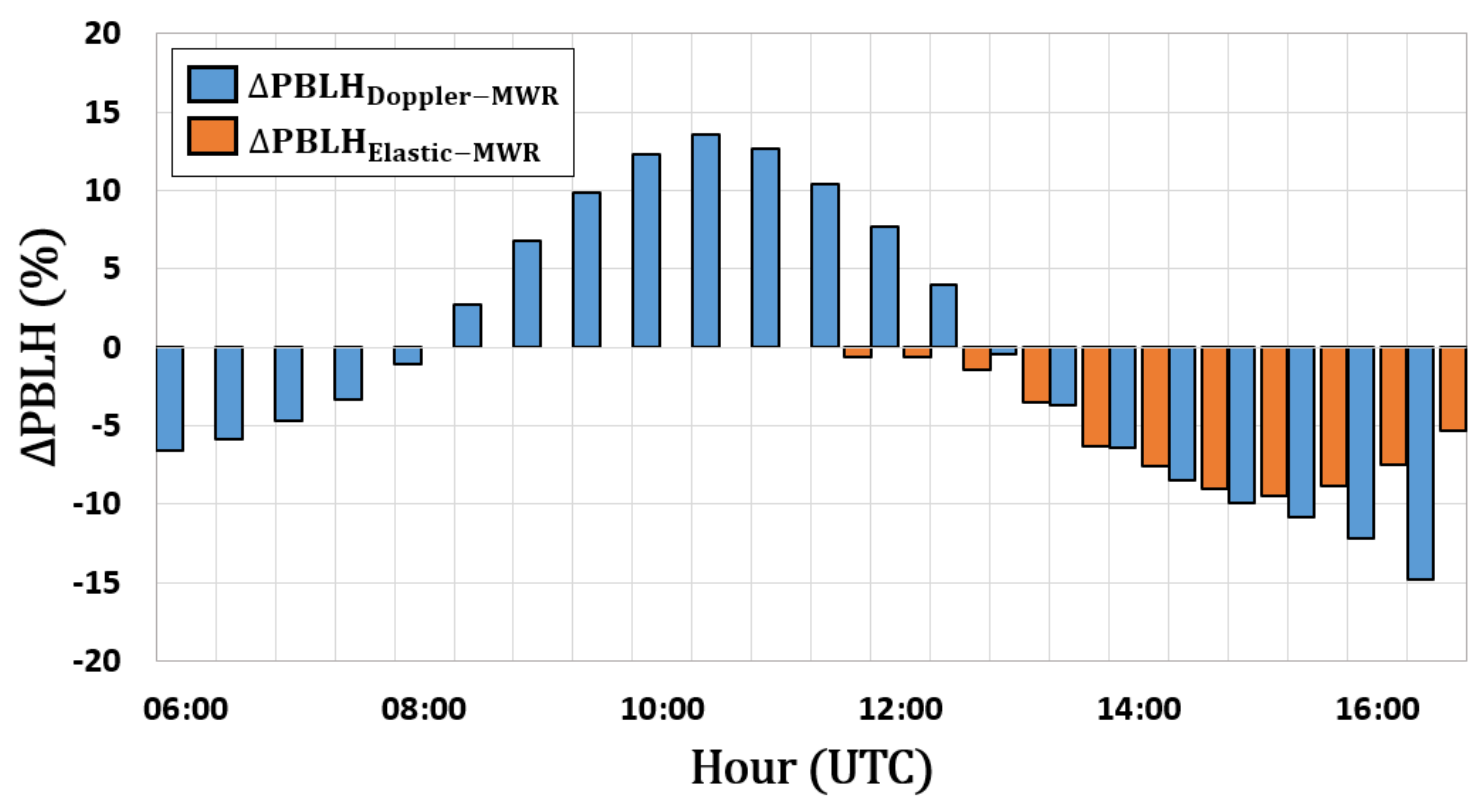

Figure 5 - Temporal evolution of $\triangle P B L H_{\text {Doppler-MWR }}$ (blue bars) and $\triangle P B L H_{\text {Elastic-MWR }}$ (orange bars).

708

709

710

711

712

713

714

715

716

717

718

719

720

721

722

723

724

725

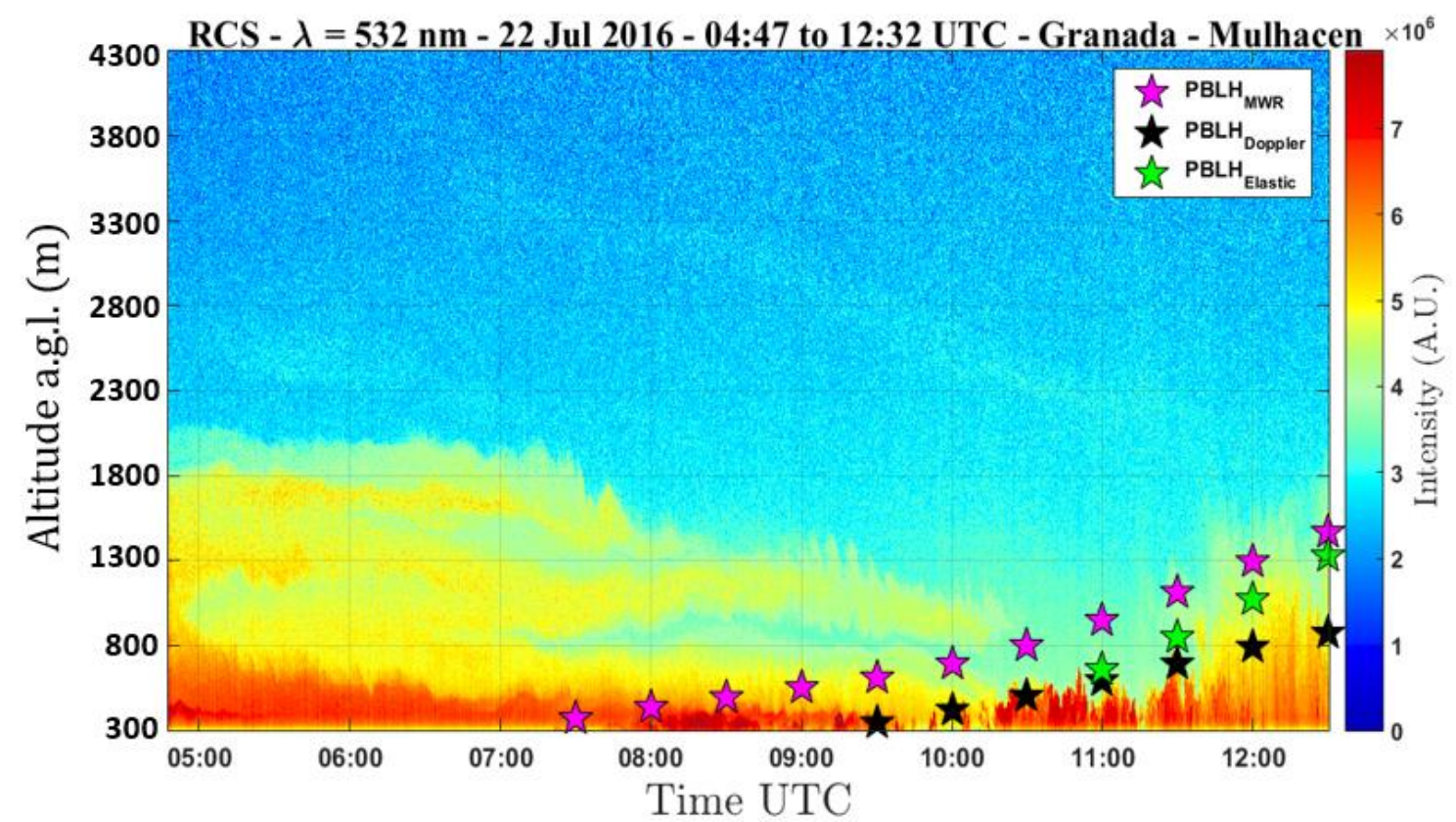

Figure 6 - Temporal evolution of $R C S$ profile and $P B L H$ provided by $M W R$ (pink stars), $E L$ (green stars) and $D L$ (black stars). 


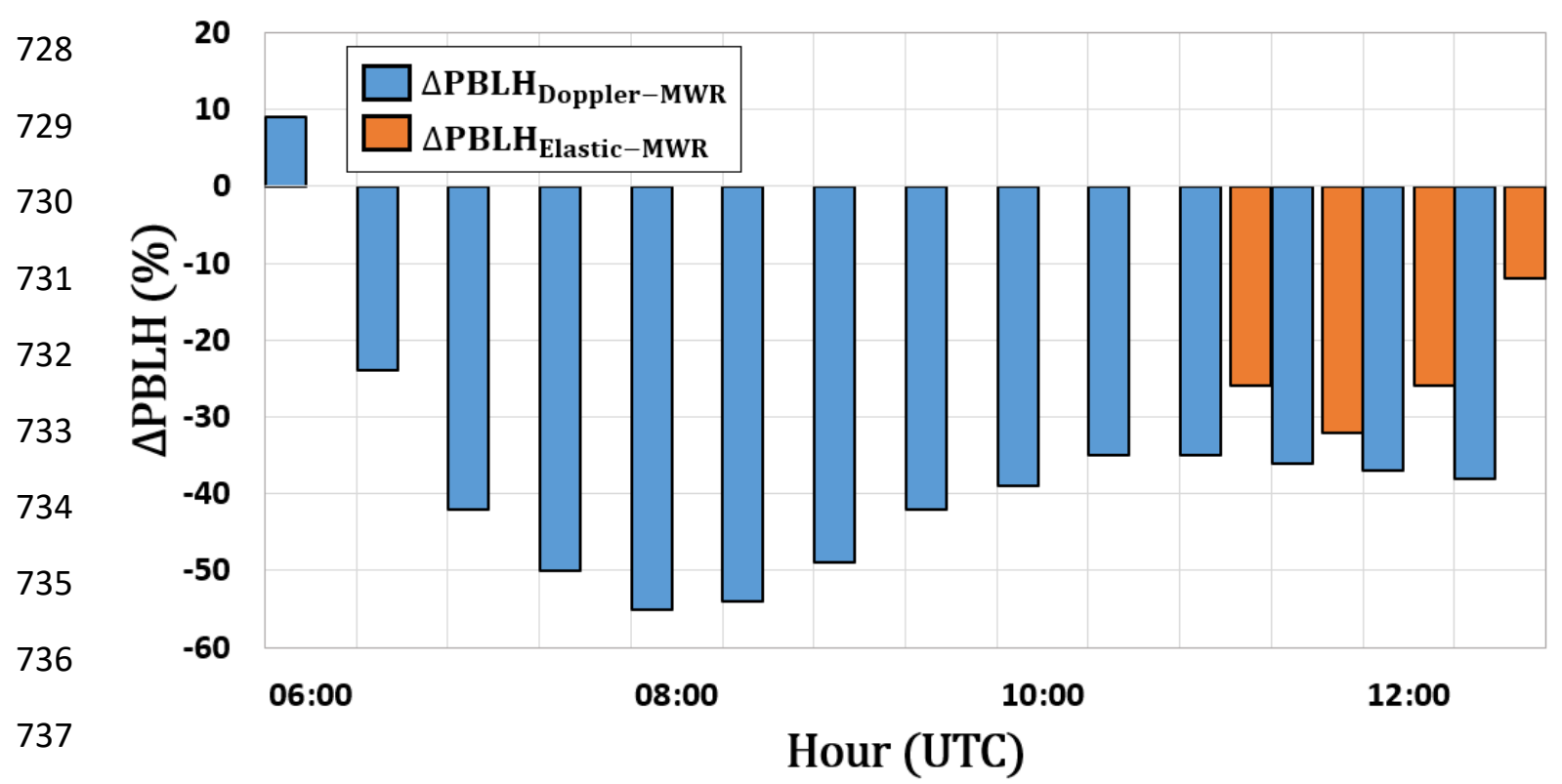

738

Figure 7 - Temporal evolution of $\triangle P B L H_{\text {Doppler }-M W R}$ (blue bars) and $\triangle P B L H_{\text {Elastic-MWR }}$ (orange bars).

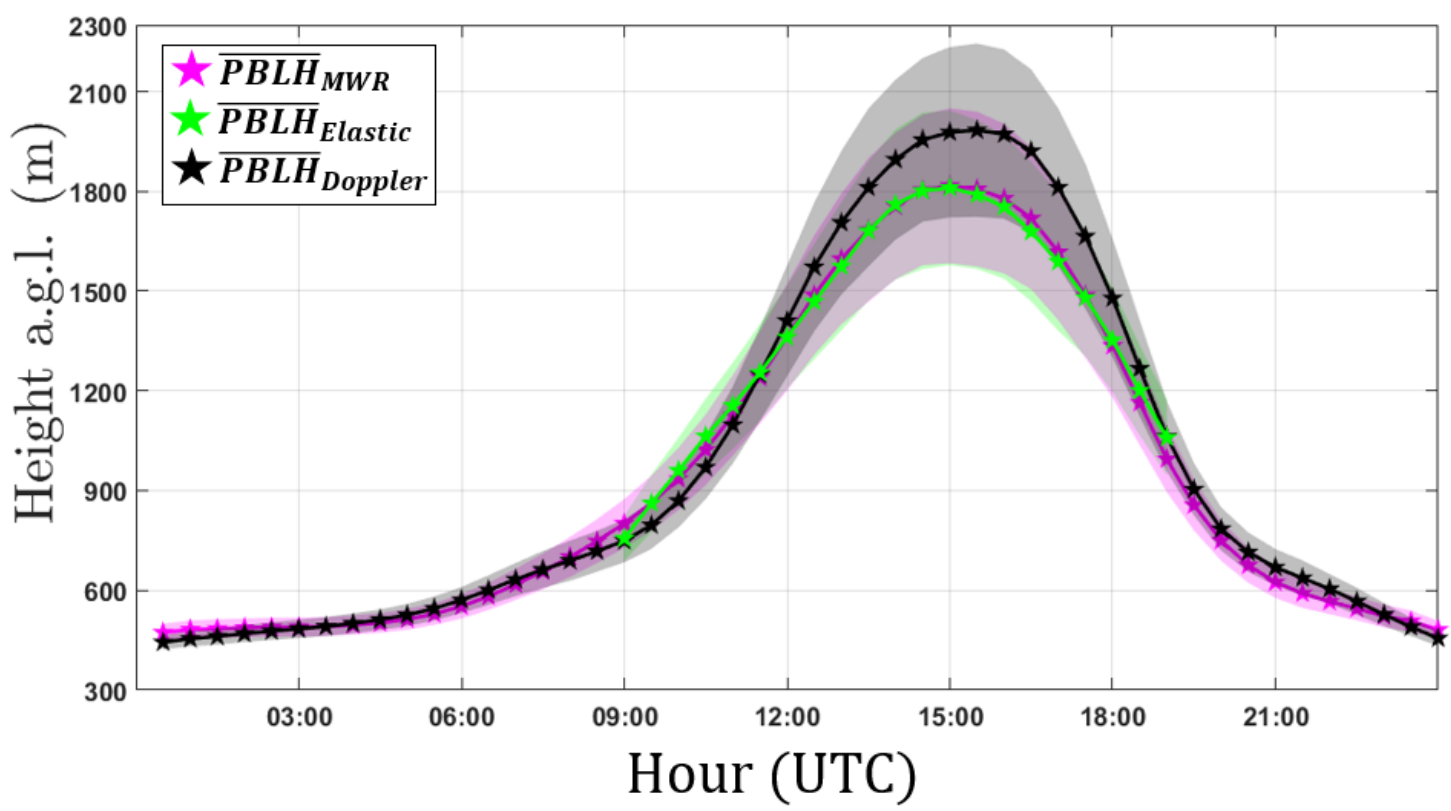

Figure 8 - Average values of $P B L H$ provided by $M W R$ (pink stars), $E L$ (green stars) and $D L$ (black stars). The shadows with the colors of stars mentioned above represent the standard deviation of respective methods.

741 
752
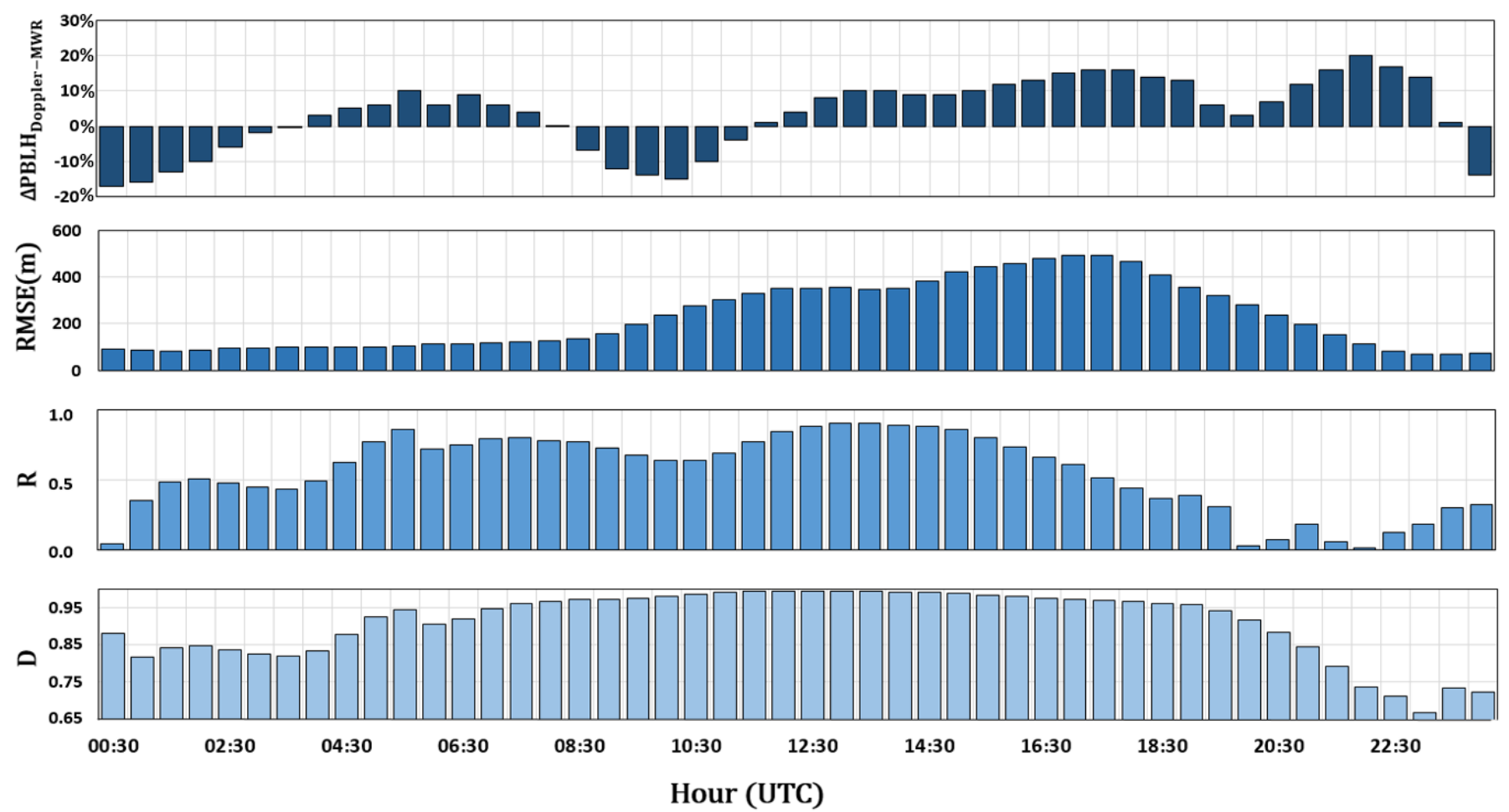

Inh

Figure 9 - Statistical comparison between the daily patterns of $P B L H_{M W R}$ and $P B L H_{\text {elastic }}$ obtained during all SLOPE-I campaign. Each bin size is equivalent to 30 minutes. $\triangle P B L H_{\text {Doppler }-M W R}, R M S E, R$ and $D$ represents average percentage difference, root mean square error, correlation index and index of agreement, respectively. 

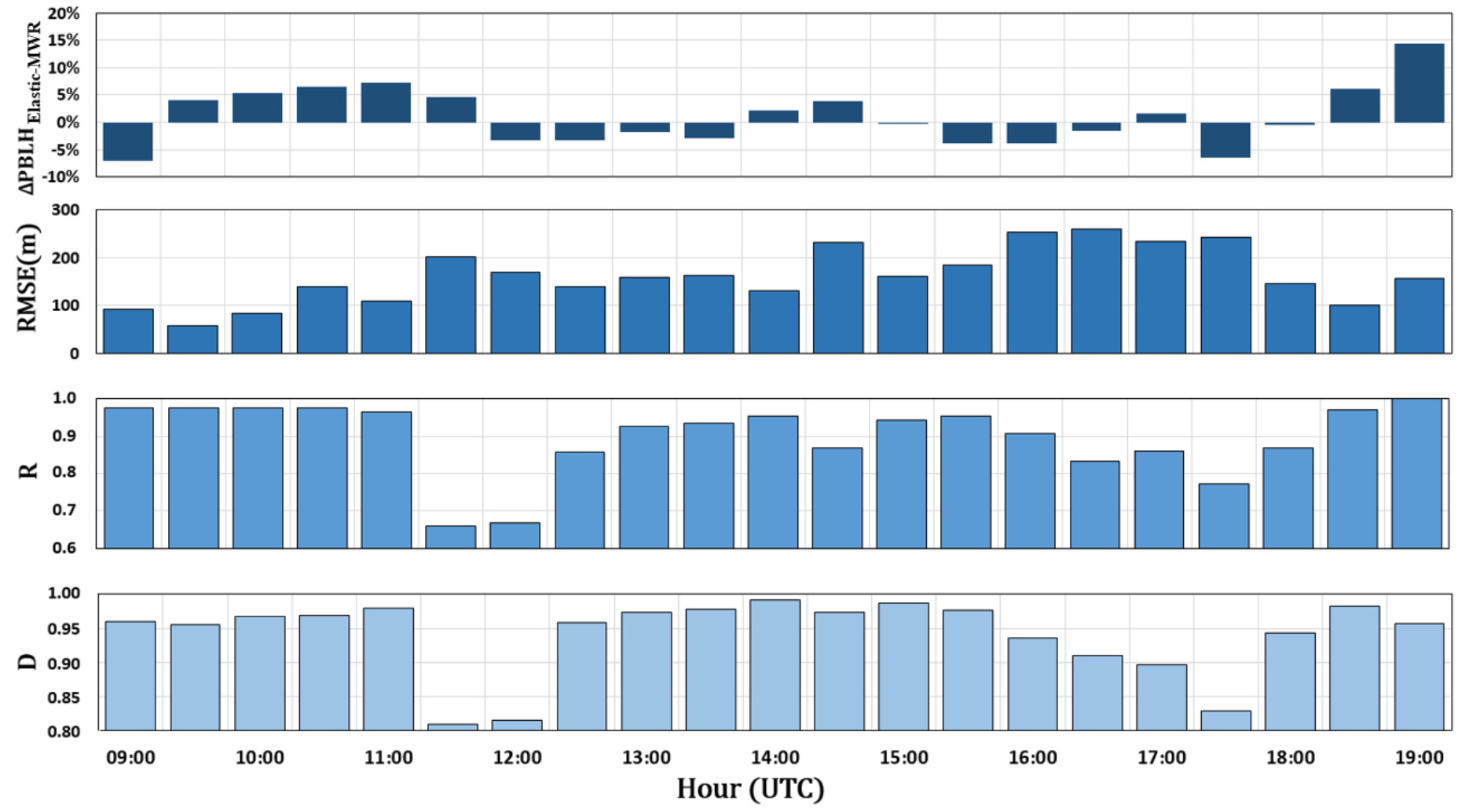

Figure 10 - Statistical comparison between the daily patterns of $P B L H_{M W R}$ and $P B L H_{\text {elastic }}$ obtained during all SLOPE-I campaign. Each bin size is equivalent to 30 minutes. $\triangle P B L H_{\text {Elastic-MWR }}, R M S E, R$ and $D$ represents average percentage difference, root mean square error, correlation index and index of agreement, respectively.

771

772

773

774

775 